Portland State University

PDXScholar

Engineering and Technology Management

Faculty Publications and Presentations

8-2-2015

\title{
Siting a Wind Farm in Oregon: Considering a Hierarchical Decision Model with Four Scenarios
}

Diane Yates

Portland State University

Follow this and additional works at: https://pdxscholar.library.pdx.edu/etm_fac

Part of the Operations Research, Systems Engineering and Industrial Engineering Commons Let us know how access to this document benefits you.

\section{Citation Details}

Yates, D. (2015, August). Siting a wind farm in Oregon: Considering a hierarchical decision model with four scenarios. In Management of Engineering and Technology (PICMET), 2015 Portland International Conference on (pp. 447-471). IEEE.

This Article is brought to you for free and open access. It has been accepted for inclusion in Engineering and Technology Management Faculty Publications and Presentations by an authorized administrator of PDXScholar. Please contact us if we can make this document more accessible: pdxscholar@pdx.edu. 


\title{
Siting a Wind Farm in Oregon: Considering a Hierarchical Decision Model with Four Scenarios
}

\author{
Diane Yates \\ Dept. of Engineering and Technology management, Portland State University, Portland, OR - USA
}

\begin{abstract}
This paper primarily serves two purposes: first, it looks to develop a methodology that takes scenarios and certain hard-to-measure intangibles such as politics, social impact, and even religion; as well as more tangible and measurable variables such as environmental impacts, cost and types of materials, storage and wind turbine technologies, to name a few, that then could be used as input to a decision-making model on where to build a wind farm. The hierarchical decision model (HDM) then analyzes these variables, based on an independent judging panel, in order to come up with a recommendation for the best site on where to build the wind farm. Second, the preliminary discussion of this paper serves as a prototype of developing a methodology that might one day serve as part of an overall comprehensive energy policy for the State of Oregon.
\end{abstract}

\section{INTRODUCTION}

Currently, there is no comprehensive energy policy, renewable or otherwise, in the State of Oregon. There is an Oregon Renewable Energy Action Plan commissioned in 2005 by then-governor Ted Kulongoski from the Oregon Department of Energy, a Renewable Energy Working Group - even a Renewable Portfolio Standard (RPS) that states "all large energy utilities must incorporate $25 \%$ of renewable energy into their portfolios by 2025." [1] However, at the time of writing this paper, there is no comprehensive policy. The danger of the lack of such policy is that renewable energy efforts risk being all over the map, the wasting of tax-payer dollars, and ultimately, the failure to attract businesses willing to build a wind farm in Oregon. Currently, corporations largely are left to their own devices in coming up for, with renewable and sustainable energy offerings. Studies have shown that without government initiatives, such efforts risk falling by the wayside, as often it is very expensive coming up with the capital investment that renewable energies require. For example, the initial installed capital costs of a land-based wind farm are fairly prohibitive - it can cost as much as $\$ 3,000 / \mathrm{kW}$ to build a utility-scale wind farm, [2] with the EROI (Energy Return on Investment) taking five years on average; but this is very dependent on turbine size, wind speed, and so on. Older, smaller turbines take longer, and newer, larger turbines take a shorter amount of time for the EROI to occur. [3] If this seems counterintuitive at first, consider the facts: larger turbines generate more wind power, and thus create more energy. This results in a faster EROI, even though smaller turbines cost less. (Note: Capital costs are dominated by, but not limited to the cost of the turbines. Annual operating costs are not factored in.)
Although renewable energy in the form of wind farms sounds good, there are some caveats. A wind farm is a viable way to generate energy that leaves a smaller carbon footprint, but there are some hard-to-measure issues, namely political, environmental, and public opinion, that can factor in the outcome of whether or not the site for a wind farm is appropriate. This paper examines some of the important issues that factor into the decision-making process, and ways to address them before the shovel breaks the ground on any wind farm project.

\section{WIND IN OREGON}

Oregon is a state full of natural beauty in the Pacific Northwest that is bordered by Washington to the north, California to the south, and Idaho to the east. The Columbia River forms the border between Oregon and Washington for nearly three-quarters of the state before it traverses northward into Washington. The Snake River forms half of the border between Oregon and Idaho. Oregon is home to many ecoregions, but perhaps the most notable change between regions occurs east and west of the Cascade mountain range. There exists northeast and east of the range arid and semi-arid ecoregions, such as the eastern Cascades slopes and foothills; and the Columbia plateau which also is flanked by smaller mountain ranges such as the Blue Mountains (the Wallowas and Seven Devils Mountains). Despite the fact that the ecoregions overall are more arid than the ecoregions to the west of the Cascades (the southeast corner of the state tends to be higher, cooler, and more precipitous than the eastern and northeastern parts of the state), parts of these regions are still somewhat influenced by marine air, such as region $11 \mathrm{c}$, the portion of the Blue Mountains called The MaritimeInfluenced Zone because it intercepts marine air travelling east through the Columbia River Gorge. [4]

The western part of the state - everything west of the Cascades - is much wetter, affected by marine air and the mountains that make their own weather by trapping some of the wetness and fog that blow in from the coast. The Coast Range is also very wet, and is home to western red cedar, western hemlock, and Douglas fir.

The north, northeast, and north-central parts of the state is home to several wind farms - such as Shepherds Flats in both Morrow and Gilliam counties - due to the fact that there are many pockets of windy areas whose wind quality are rated from good to superb (at $50 \mathrm{~m}$ ), according to the U. S. Department of Energy, National Renewable Energy Laboratory. These wind farms also have the advantage in that most are close to the existing electric grid. However, none 
comes close to the abundant wind quality and quantity — rated from excellent to superb - that exists all up and down the Oregon coast. [5]

An online article by Elizabeth Harball states that floating wind turbines may be coming to the Oregon coast by the end of the decade. [6] Principal Power of Seattle plans to build a 30 megawatt offshore wind farm, called the WindFloat Pacific Project, at a test site consisting of 5 units tethered 16 nautical miles from Coos Bay, Oregon. [6] Although the project still has to go through some policy hurdles, it appears to have the support of Oregon Governor John Kitzhaber, U.S. Secretary of the Interior Sally Jewell, and BOEM Director Tommy Beaudreau. Offshore wind farms are already part of the grid in Europe, in the United Kingdom, Belgium, Denmark, Germany, Sweden and Spain, to name a few. [7]

\section{WIND FARM REGULATIONS AND GOVERNMENT}

It is expected that government has a role in siting and permitting for wind farms. Oregon does, in fact, have siting processes, rules and statutes, and standards. [8], [9], [10] These fall under the governance of the Oregon Department of Energy (ODOE). The agency responsible for large facility siting is the Oregon Energy Facility Siting Council. The ODOE states that certain types of energy facilities, by order of the Oregon Legislature, must be reviewed by the Council. [11] An energy facility developer must apply for a site certificate, supplying information about the "proposed facility and the proposed site". This holds true no matter what type of energy facility it is - whether it is natural gas, biomass, or wind farms. The agency expects the site developer to supply information on where it wants to build, and the type of facility. It is apparent from looking at the standards and processes web site, that companies who have some understanding of standards and practices would have an advantage, because there is complexity in the process.

However, having an understanding of Oregon's standards and practices does not necessarily guarantee success with establishing a wind farm.

\section{Other Governmental Influences}

What is not explicitly stated are nuances in the kinds of funding and types of support a developer may or may not encounter due to the type of government in power at the time of the proposal. This variable affects outcomes at both the federal and local (state) levels. There are many reasons why this matters; one of the more important reasons is how government provides financial support in the way of grants, loans, tax breaks, and matching funding, often based on political ideology.

There are three branches of government in the United States at the federal level-the Executive (President, Vice President), the Legislative (Congress), and the Judicial (Supreme Court). Politics in the U.S. are dominated largely by a two-party system, the Democratic Party and the Republican Party. Although there are other parties, such as
Libertarians, Independents, the Green Party, the Constitution Party, and some other minor parties - on a Federal level at least-Democrats and Republicans comprise the majority of government. In the two branches of Congress, this consists of the Senate (53 Democratic, 45 Republican, 2 Independent), [12] and the House of Representatives (201 Democratic, 234 Republican) (113 ${ }^{\text {th }}$ Congress). [13] At the time of writing this paper, both the President and Vice President are Democrats. The Supreme Court is a mixture of Democrats and Republicans; individuals are appointed by the President as an opening presents itself, and are approved by the Senate. State governments have an executive branch, legislative branch, and a judicial branch as well. While there are sometimes more political parties, especially on a local level, the twoparty system still dominates.

The two-party system comprises mostly of liberals (Democrats) and conservatives (Republicans). These two ideologies often cause polarization in government, which in the worst case, causes one party to block or undo the initiatives and actions of the other. Not only does this affect how government conducts its day-to-day business, it also affects how government uses and distributes money for science and business, (in the form of grants, loans, and tax credits); and also in the way it goes about permitting companies to conduct business.

The subjects of liberalism and conservatism in government could probably fill an entire college course. The subject is complex, but it is a key proponent of my model. It is probably important to define what liberalism and conservatism is, especially in terms of doing business. It is easy to over simplify its effects on business, but its impact should never be underestimated. A lot has been written and opined on it; because of its ability to affect the outcome of the model, subject matter experts (SME) should have an understanding of the dynamics based on whether the government is conservative or liberal, or have somebody on the team who does. Information about the two points of view abound on the Internet, but a synopsis in the form of side-toside comparisons

In his article, Liberalism and Conservatism and Their Effect on Business in General, Michael Matthews [14] states

"The American political landscape is defined in large part by the fundamental differences between liberalism and conservatism. Their divergent values and opinions affect business in general as well, for better or for worse. .."

One example of how politics affect business was the recent problem President Obama had with a Chinese firm building four small wind farms near the Boardman Naval base because the military flies "unmanned drones and electronic-warfare planes on training missions." The article went on to state that it had been the first time in 22 years that a U.S. president blocked such a foreign business deal, citing concerns about "the Chinese using the sites to gather information on U.S. advanced weapons systems". [15] 


\section{Proceedings of PICMET '15: Management of the Technology Age}

Perhaps if this Chinese firm had bothered to consider the political ramifications of building a wind farm site so close to the Naval base, it would not have invested time or money into the proposal. Instead, it is challenging the decision in a lawsuit. [16]

\section{PUTTING TOGETHER THE MODEL}

The model is designed such that SMEs consider one of several political scenarios. Within each scenario are variables such as environmental, socio-political, and technical aspects. Variables remain the same across all scenarios. For simplicity, not every conceivable variable is considered; the variables chosen are those that are important to the discussion for the region. In reality, there could be other variables to consider when using AHP or HDM in the site selection decision-making process. The main point of the paper is to illustrate how the variables in the given model may change in importance given a certain scenario. Taking these scenarios into account allows for advanced planning, and to ascertain whether or not the project is feasible.

\section{A. Scenarios}

The model was built using the HDM decision-making process to be evaluated inside one of four scenarios. Each scenario is evaluated separately. All four scenarios may be evaluated for any given project; but what is likely more useful is to evaluate the project given the situation most important to the decision.

The outcome of the model is the choice between two possible sites that could support a wind farm. Both of these sites would be evaluated using the methodology outlined here. The two examples in the model represent different land parcels that present unique opportunities and challenges in making the decision. Opportunities and challenges are represented as variables that must be taken into consideration when selecting a site. Using scenarios as part of a multiplecriteria decision model allows for some contingency planning up front, as well as enabling the best fit for the project. The scenarios are as follows:

- Liberal Government + Booming Economy

- Liberal Government + Recession

- Conservative Government + Booming Economy

- Conservative Government + Recession

The model is designed to be used when there is more than one site under evaluation, but could be used to evaluate a single site. The variables are configurable also. Not every variable is under consideration, however; to keep the evaluation manageable those variables deemed to be most important should be selected. Keeping the set of variables relatively small makes it easier for the SME to make the evaluation. Thus, not all aspects of building a wind farm are considered. For example, economics is not considered in this model. The purpose of this paper is to demonstrate how the methodology works. Given the different scenarios, the variables will have different values and weights. This is what the potential panel of experts must take into consideration when deciding where to build the wind farm.

For the purpose of using the model, the following definitions are an approximation on how to evaluate the model within a given scenario: a liberal government and a booming economy means that there probably is more federal and state money for grants and tax credits; permitting is not as onerous, but jobs that the potential wind farm creates must be balanced against the potential negative environmental impacts that wind farms create. These environmental impacts are weighed in the context of socio-political opinion and not mere environmental impacts; rather public perception of the impacts.

A liberal government and a recession might mean that tax funding and government grants dry up or are harder to obtain. There is the political consideration of environmental impacts; however, in a recession people might be willing to overlook some of the environmental impacts (noise, obstructed view, and so on) for gains in employment. A recession likely means less government funding to start new projects, or even finish existing ones.

A conservative government and a booming economy likely means that jobs will be more important than environmental considerations. Concerns towards migratory birds and bats will be offset with the possibility of a robust economy in the region. The permitting process is easy, and oversight probably is pretty lax---the Company that builds the wind farm self-regulates, probably much to the dismay of environmentalists. Also, a booming economy means that the private market sector is able to raise money and invest in wind power without taking money from the federal government.

Likewise, a conservative government in a recession might not be too concerned about providing tax breaks for renewable energy. A recession would likely have a deleterious effect on revenue, thus federal and state funds potentially could dry up for renewable projects. However, jobs are very important, so a conservative government might relax the permitting process. Other considerations a conservative government might undertake in the spirit of saving taxpayers money would be to outsource environmental policing to the Company building the wind farm, (maybe with potentially disastrous results). These are just a few considerations that these various scenarios present.

\section{B. The Scenarios - Discussion}

"Political will and the right mix of policies - not vast resource potential-have made wind and solar power the world's fastest growing energy sources over the past decade," says Worldwatch Research Associate Janet Sawin [17][18].

If this assertion is true, then what constitutes "political will'? In the United States, there are two main political parties. On the federal level, the major players are the Democrats and the Republicans. Independents hold a very distant third place-two seats as of this writing-in the 
Senate, and none in the House of Representatives. There are other parties that factor in local elections, such as the Green Party and the Constitution Party, to name two. The Democrats tend towards liberal views and policies and the Republicans tend towards conservative views and policies. In a political sense, what does this mean?

Studies consistently show that liberal political affiliations tend to be supportive of environmental issues like renewable energy; however, one study states that mainstream politics, whether liberal or conservative, give scant attention on their own to environmental issues. Neil Carter, in his paper says that in Europe the Green Party dominates the environmental discussion, even though some say the Green Party is not the same in every country. However, most agree that the party is associated with strong environmentalism, equality for women, eradicating poverty, and other socially conscious issues. He also says that as mainstream government vies for more environmental awareness, they benefit from negotiations with the Green party [19]. The study did not mention politics in the United States; the Green Party does not have the same political clout in the U.S. as it does in Europe, at least on the Federal level.

In their paper, Diane P. Dupont and Ian J. Bateman examine how political affiliation affects a willingness to pay (WTP) for environmental goods such as renewable energies. Their research involves water resources instead of renewable energy, but their results can be extrapolated to any environmental resource. Their study involves research conducted in Great Britain, studying party affiliation along British Labor and British Liberal parties, and the British Conservative party; but they extrapolate their findings to American politics-Democrats and Republicans-liberals and conservatives, respectively [20].

Initially, their findings indicate that WTP falls along political affiliation, with those identifying as conservative having a much lower WTP for environmental goods than those identifying as liberal. However, their second and third surveys changed the context and asked subjects whether they would support environmental goods if the means of payment was collective (public) or private. In this context, conservatives show a higher WTP for environmental goods if the mechanism for payment was private instead of public. What the study concluded is that conservatives tended to trust market enterprise solutions to provide services and goods as opposed to paying for them with public funds (in the form of taxation). They also found that liberals tend to express WTP independent of where funds originate. Their findings indicate that conservatives are not necessarily against paying for environmental goods and policies, but prefer that the means come from private enterprise instead of the government.

As the DuPont and Bateman paper showed, choosing the context you measure can change the outcome of the study. Asking the right questions matter. In the case of environmentalism and wind energy, it may be a revelation that conservatives are not against renewable energies - the question revolves around who is going to pay for it.
Another study that seems to support the fact that the conservative/liberal divide regarding environmentalism - and its goods and services - is not as simple as liberals "for" and conservatives "against" - is written about by Richard Craig Crouch and Dorian S. Abbot. In their paper, "Is Green Education Blue or Red? State-Level Environmental Education Program Development through the Lens of Redand Blue-State Politics," [21] they learned that the practice of teaching about environmentalism in the classroomsometimes seen by conservatives as pushing a "liberal agenda"-is not just a liberal policy goal. Through the application of quantitative statistical methods, the study's authors found that there were no statistically significant differences in degrees of $\mathrm{EE}$ classroom programs and participation between Democratic states and Republican states, indicating that political affiliation was not a reliable indicator of the state's level of EE educational participation.

Taking up this argument in his online article, "What Are the Conservatives Big Ideas About Clean Energy," Stephen Lacey [22] tells the story of Republican congressman Michael Grimm (R-NY) whose home on Staten Island was destroyed in 2012 by Superstorm Sandy, and how this topic was part of a discussion he had with another Republican. In an episode of Years of Living Dangerously, Lacey tells us that Grimm sat down with fellow Republican, and former South Carolina congressman Bob Ingliss to discuss the threat of climate change. Lacey says that Ingliss lost his seat to a Tea Party challenger in 2010 due partly to his efforts of finding market solutions to reducing climate pollution, and implementing renewable energies. In their televised interview, Ingliss asked Grimm why Republicans did not accept climate change data as scientifically proven. Grimm's response was that it was not so much that Republicans did not trust science, but that if credence was given to climate change, then that would create an atmosphere for more rules and regulations.

Lacey argues that it would seem that Republicans ignore the obvious because for too many years, they let liberals dominate the discussion around climate change. And because climate change is now seen as a liberal construct, too many conservatives feel compelled to oppose it in principal, to the point of failing to put forth any real market solutions that address climate change and clean energy. And he asserts that the same political dissent Republicans have with liberals is holding back the industry.

Michael Liebreich of New Energy Finance agrees with that assertion. Not only has the political right liberals dominate the discussion on the environment and renewable energy, he feels that the Republican response of oppose and ignore instead of seeking out market solutions could derail the renewable power industry in the long run. He feels that less regulation, not more, is needed. Liebreich is part of a conservative consortium consisting of business, economic, and scholarly individuals who apply right-wing thinking to the environment. Called the Conservative Environment Network (www.cen.uk.com), its members seek answers to 


\section{Proceedings of PICMET '15: Management of the Technology Age}

today's environmental concerns within a conservative framework where less government is more, and free market enterprise is the solution. In a document called "Responsibility \& Resilience: What the Environment Means to Conservatives," he pens an essay ("Clean energy needs less regulation, not more") outlining that unnecessary regulations and planning costs are keeping renewable energy prices unnaturally high. Free market enterprise, not more regulation is needed in order to bring down costs and increase profits [23].

At the other end of the argument are those who believe government involvement is the key to the promoting renewable energy. According to Claudia Hitaj, wind power development in the United States depends on two things: government renewable incentives, and access to the grid [24]. She states that both state and federal incentives play a key role in promoting wind energy. The major federal incentive is called the renewable energy production tax credit (PTC). Instituted as part of 1992's Energy Policy Act, it was extended six times, having recently expired in 2012. However, some renewable projects that were already started when the PTC expired are given a certain amount of time they may still claim the tax. Oregon has a handful of incentives in the form of tax credits large scale and small scale (residential) wind farm owners may claim. These tax credits include Business Energy Tax Credits and Renewable Grants, and the Residential Tax Credit, to name a few [25].

This paper does not go into the historical role governmental policy that has played in facilitating energy growth, particularly wind, in the nation. There are many good articles that do this. Two articles that discuss the role of government policy in promoting wind energy over the years are Vicki Norber-Bohm's “Creating Incentives for Environmentally Enhancing Technological Change: Lessons From 30 Years of U.S. Energy Technology Policy" [26] and "Enabling the Widespread Adoption of Wind Energy in the Western United States: the Case for Transmission, Operations and Market Reforms," by Jennifer E. Gardner and Ronald L. Lehr [27].

Thus one can ascertain from the limited discussion presented here that the issue of implementing renewable energies such as wind power can very be much influenced by ideology. This ideology — whether conservative or liberalcan affect renewable energy policies and funding. To say that these factors are complex and difficult may be true, but they are very important for the expert evaluation within each scenario; indeed, they are the crux of the evaluation.

\section{HDM (Hierarchical Decision Model)}

The model used for the expert judgment panel is HDM. Both AHP and HDM have been well-studied and are used extensively throughout academia and industry. A summary of the methodology is presented here.

Both AHP and HDM are multi-criteria decision-making methodologies that quantify expert judgment in order to select one alternative or outcome over others. The method is hierarchical, with the top of the hierarchy being the desired outcome (such as wind farm siting) with subsequent sublayers, down to the bottom layer that contains several alternatives. The bottom layer in this exercise would be potential sites for a wind farm. Multiple criteria go into making the decision, which are evaluated through pairwise comparison. This is where the experts add their value, as the experts decide what value to give each pair in the comparison. Pairwise comparison is performed through each layer of hierarchy.

AHP and HDM have been used and studied extensively as a research and decision-making tool for future energy considerations. For example, it has been used in allocating a wind farm site in Malaysia [28], and in China [29], to name a few. In their paper, A Holistic Approach for Wind Farm Site Selection by FAHP, Talini et al construct a decision-making matrix that is very similar to the one used in this paper. However, they do not use different scenarios with their model. [30] Also, only three objectives are considered for this model: technical, environmental and socio-political.

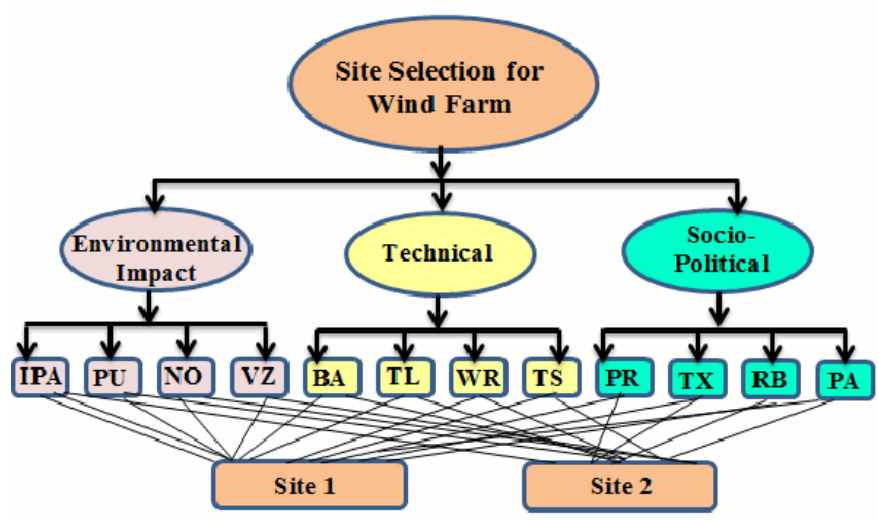

Figure 1: Hierarchical Model for Wind Farm Siting Method

\section{THE VARIABLES}

The variables used in this model were chosen because of previous references to them in the literature regarding wind farm siting and methodology (Refer to table 1 in Appendix). There are other variables that could be used; the model allows the user to construct the hierarchy using any variable deemed to be important to site selection. For example, economic variables could be used in lieu of one of the variables in this model. a

Technical and environmental impacts are often studied when siting a wind farm, but socio-political considerations are not as frequently studied in the literature, at least in the HDM/AHP model. This is one reason this variable was included in this model.

The following is a list of some variables to be considered as input into site selection, and whose contents go into this analysis. (This list is not comprehensive, but is used for developmental purposes): 
Environmental Impact Variables

- Impact to plant \& animal species

- Noise blades make

- Proximity to urban centers, neighborhoods

- Visual impact

Technical Variables

- Battery/storage technologies

- Proximity to transmission lines

- Reliability of wind

- Turbine size/position

Socio-Political Variables

- Perceived risks to wildlife

- Availability of tax credits/carbon credits

- Religion/belief systems (such as Native American beliefs)

- Public acceptance

\section{The Variables - Discussion}

In this section I discuss the variables in the model, starting with the variables that have environmental impact.

\section{Environmental Impact Variables}

I chose four variables - the impact to plant and animal species, the noise wind turbine blades make, proximity to urban centers and neighborhoods, and the visual impact the wind turbines make - as the environmental impact variables because they frequently occur in the literature and in discussions about negative factors concerning wind turbines and wind farms. These four do not represent an entire list of environmental impacts, however. For example, one concern not investigated here are the potential interference with radar and telecommunication facilities and another regards offshore wind farms acting as artificial reefs and fish aggregation devices (FAD) for small demersal fish, thus potentially changing the makeup of the marine environment around them. [31]

Wind farms are touted as being a solution to polluting carbon energies so that it is easy to overlook the fact that the environmental impact is not neutral, or even all positive. There are some well-documented negatives concerning the environmental impacts of wind turbines and wind farms.

The impact to plant and animal species: Much concern has been expressed about the impact the turbine's blades has had on aviary (birds and bats), [32], [33], [34]. While there is some evidence that the blades from the wind turbines increase avian mortality, there is scant long-term data to analyze [35], and there also evidence that birds learn adapt to adapt to the turbines over time [36].

Noise blades make: Another environmental concern is the noise the blades make. One study [37] suggests that although there is no physiological effect of noise, there is an annoyance affect that the turbines cause; related to, among other things, the sensitivity and perception of the noise upon the individual. Turbine size and proximity to an urban center factor into noise perception - especially on windy days when the turbines are going 24/7 [38]. Also, one study on perceived annoyance on noise from wind farms, it was found that people were more likely to be annoyed when A-weighted sounds pressure levels exceeded 35-40 dB. The same study states that subjective factors such as "having turbines visible from the dwelling, negative opinion about wind turbines in general and/or their visual impact on landscape, and selfreported sensitivity to noise increased the probability of being annoyed by the wind turbine noise." Also positively correlated with perceived annoyance with noise is terrain and whether subjects lived in close proximity to an urban setting - and whether one can see wind turbines from one's home. Conversely, those subjects who viewed wind farms as having positive tangibles like economic benefits was associated with a reduction of noise annoyance [39].

Proximity to urban centers, neighborhoods: Another environmental variable that is built into the model is the proximity to urban centers and neighborhoods. As stated in the previous paragraph, there is a positive correlation with annoyance surrounding wind farms in close proximity to urban areas. There is a good amount in the literature that discusses this factor, and looks at it with different lenses. For example, one article discusses methodology used to ascertain public attitudes towards wind farms in Texas. Four factors were studied: proximity to the wind farm; any physical or environmental factors influencing attitudes; the NIMBY phenomenon; and how attitudes towards wind farms change over time [40]. Most studies show public support for wind farms in theory; in practice many projects suffer from NIMYism: NIMBY meaning Not In My backyard [41]. Maarten Wolsink states that while the public may support renewable energies like wind power, wind farms are a different matter. The largest opposition to the implementation of wind farms is the visual impact to the view. Interestingly, his articles state that opposition is due to miscommunication with the public, and states that the NIMBY factor is outdated. Instead, fairness and equity are seen as two dominant factors in the so-called NIMBY factor instead of selfishness [42] [43].

Visual impact: The last environmental variable is visual impact. Visual impact was a factor in several other environmental impact studies, but there were some articles that dealt with the aesthetics of wind farms exclusively [44]. Interestingly, one study used the concept of beauty from complexity theory to see which attitude was objectively more truthful: the attitude that says wind farms are to be appreciated because of their ecological rationality but not their looks; and the other attitude that appreciates the wind farm's aesthetic due, in part, to its ecological rationality [45]. Another study states that it is the visual impact of the wind farm on the environment as a whole that creates the objection. Developing a multi-criteria way to assess the objective impact that wind farms have on the environment is seen as one indicator that can be measured and factored into public objection to wind farms [46]. 


\section{Proceedings of PICMET '15: Management of the Technology Age}

\section{Technical Variables}

Battery/storage technologies: Because of the nature of wind is such that it is intermittent much of the year, and the fact that the electricity must be used as it is generated, professionals are looking to storage technologies to help mitigate these inherent problems. Battery Energy Storage Systems (BESS) are one such technology that mitigates the peaks and valleys of the load in energy systems. BESS provide "an extremely fast interface between the ac network and the battery dc energy storage. They can produce both active and reactive power for the ac network, even though the batteries only store real (active) power" [47]. BESS have been deployed on wind farms in Japan, and have been met with success [48]. BESS design methodology have been considered for wind farms in which BESS energy capacity required depends on the power dispatch strategy used [49].

Proximity to transmission lines: Proximity to transmission lines, or the grid, is a concern in wind farm siting. As opposed to battery storage, where backup generation can be reduced by storage - averaging in timegrid extensions - averaging in space - can be a significant cost, both economically and in terms of space. If backup power is to come from a truly renewable source, then costs cannot be prohibitive [50]. However, it has been argued that large grid extensions, from the perspective of exploiting the most favorable RES-S sites throughout Europe, are beneficial through a "least cost" perspective [51]. Regarding offshore wind farms, one study assessed that the U.S. has enough offshore wind potential to have at least $54 \mathrm{GW}$ of energy by 2030. However, high upfront capital costs and permitting costs could potentially derail efforts if special considerations are not taken into consideration. The study did assert that appropriate technologies exist for interconnecting large amounts of wind energy to the U.S. grid [52].

Reliability of wind: The next variable in the model is wind reliability. Wind reliability is also known as high value wind, wind energy potential, and wind power potential (WPP), to name a few of the more frequently used terms. WPP is probably one of the most important, if not the most important variable when siting a wind farm. Measuring the quality of wind has been a major part of more than one study. One methodology states that the Hellman equation, and in particular the $\alpha$ exponent accurately describes wind speed characteristics as a function of height.

$$
\frac{\mathrm{v}_{2}}{\mathrm{v}_{1}}=\left(\frac{\mathrm{h}_{2}}{\mathrm{~h}_{1}}\right)^{\alpha}
$$

The variations and roughness of the terrain factors in the equation too, especially where values of $\alpha$ are concerned. Another factor that affects wind quality is the time of the day [53].

Another article talked about wind analysis in Turkey. In order to analyze the WPP the study considered three phases. Phase one entailed a five-layer analysis using MatlabSimulink to perform "a five-layer Sugeno-type ANFIS model." This analysis sought to define the relationship between wind speed and other climate variables. Phase two used another tool called WASP to complete the analysis using wind speed data. Finally, phase three completes the analysis calculates the amount of electricity that can be generated in each site and capacity usage rated of each installed turbine [54]. And yet another study used the Weibull distribution function to determine WPP [55]. And these three methodologies are by no means the only methodology used to determine WPP; there are many others.

Turbine size/position: The final variable I consider in the technical variables section is turbine size and/or position. Factors such as the size of the wind farm, the variability of the wind, and the placement of the turbines determines the size and type of the turbine used. Often, a combination of analytical methodologies are used to help decide which turbines to select; methodologies such as interpretive structural modeling (ISM), fuzzy network analytic network process (FANP), and other multi-criteria decision model, such as analytical hierarchy process (AHP) and analytical network process (ANP) [56]. Other methods of wind turbine placement uses least square fitting to determine turbine fitting [57], and another study looked at variable size turbine array within the wind farm as a method to capitalize on the WPP of a site [58].

\section{Socio-Political Variables}

Perceived risks to wildlife: This variable is often correlated with other environmental impacts, such as acoustics (noise), aviary (bats and birds), and visual impact. However, this variable addresses just the public perception on the perceived risks to wildlife, as opposed to a measurable environmental impact.

The fact is that many prime wind farms sites also happen to be very attractive to birds. Many sites are constructed in mountain passes, which also happen to be migratory bird routes. The impact to birds is probably one of the more wellknown environmental impacts, and the impact of turbines on aviary populations is a well-known public concern [59].

Aviary is not the only wildlife examined, however. One study looked at multiple use off-shore wind farms in the German North Sea. Conserving the marine environment was important in the consideration of creating wind farms, but there were many competing factions, with each having its own opinions and considerations. For example, fisheries and fishermen wanted to preserve their business operations, while environmentalists were concerned with maintaining a favorable environment for the flora and fauna that exist there [60]. Many of the research articles used questionnaires to assess public opinion on subjects like environmental impacts of wind farms [61].

Available of tax credits/carbon credits: Another variable that can influence the construction of wind farms is the availability of obtaining tax credits and/or carbon credits. These are usually given to the corporation or entity constructing the wind farm, and are usually given by the 
federal and regional governments. Obtaining tax credits can help offset the high capital costs of building the wind farm.

One study looked at small, local, community-based wind farms in Oregon. They differ from large, corporately-owned wind farms whose owners do not live in the local community, or even in Oregon. The Oregon Business Energy Tax Credits (BETC) can provide $50 \%$ of project costs [62][63].

The federal government also has tax schemes and other types of incentives for renewable energies, including wind farms. These incentives include tax credits, but also include $\mathrm{R}$ \& D funds, demonstration grants, and other financial incentives [64]. Other renewable energy schemes include feed-in tariff and the renewable portfolio standard, especially in other countries [65].

Religion/belief systems: Another socio-political variable is religion and belief systems. There is some is some debate as to how much socio-political aspects affect the outcome of wind farm siting, but there is no doubt that it is not neutral. While studies show the majority of people support wind energy, there is still some opposition to implementing wind farms. Researchers are still trying to understand the dichotomy. While some say NIMBY is mostly unsupported in reality - in order for an attitude to be true NIMBY, the individual must hold two opposing views: the individual must both agree with wind power in principal, but disagree with its implementation - there are still individuals who disagree with the idea of wind power altogether. What researchers agree on is that people who disagree with wind farms are not necessarily ignorant or misinformed [66]. So what could be influencing their attitudes?

One study regarding public opposition was the Cape Wind Project off of Cape Cod. Some of the environmental concerns had to do with Cape Wind's adverse impacts on the view, and "sacred Native American rituals" [67]. For Native Americans, the belief that nature is part of a kinship system inhabited by relatives and other mythical creatures. This belief system enhances environmentalism, but is based in spirituality [68]. Other studies indicate that there is an array of factors that affect public support for wind energy. Some of those factors are education, age, gender, party affiliation, and ideology [69].

One study in particular sought to tease out how religious beliefs affected environmental attitudes [70]. While the outcome of the study indicated that those individuals who held no religious beliefs correlated with being the most environmentally supportive, there was some environmental support in varying degrees, depending upon which religion a person belonged to. It should be noted that the term religion is narrowly in terms of various Christian groups in America. While Mormons were the least environmentally concerned, those identifying as Christian or Catholic scored somewhere in the middle. The same study indicated that Republicans scored lower than Independents, who scored lower than Democrats.

Public acceptance: There are a lot of studies on the public acceptance of wind farms, or a lack thereof. However, this variable deals only with those factors that facilitate public acceptance.

One study looked at community attitudes regarding wind farms in the rural Midwest of the United States [71]. The study looked at wind farm acceptance in Benton County, a rural county in north-central Indiana. Although Indiana voted for Obama in 2008, it flipped in 2012 and voted for Mitt Romney [72]. Questionnaires were used to gather opinion, and the rural study indicated that "on the whole, the community presents a front of acceptance" for the construction of wind farms. However, the reasons for supporting wind farms were largely economic, not environmental. This may be because conservatives are more likely to support an industry due to economic reasons rather than environmental.

Another research project regarding rural wind farms in Huron county Michigan uses Social Exchange Theory (SET) to help explain people's interactions with the environment. While the creators of the study theorized that economic reasons for community support would dominate in the study, that was not the reason for the study, or the only factor examined. In fact, the study sought to close the gap between people who support wind energy in theory, but may have problems in the implementation phase of wind farms. Unlike the previous study about wind farms in Indiana, economic factors were not the most prevalent factor for support of wind farms. Two dominant reasons for public support of wind farms were environmental and social beliefs. Once again, surveys and questionnaires were the method of gathering data [73]. Both of these studies, and others like them, indicate the importance of community input. And, it is important to remember that a one-size-fit-all does not apply to community support (or lack thereof) to local wind farms.

Studies conducted in Ireland and Scotland indicate similar results. One study examined local community attitudes towards proposed and actual onshore wind farms. Some counterintuitive facts emerged: (a) locals are more likely to support wind farms after construction than before construction; (b) The degree of acceptance tends to increase the closer in proximity to them; and (c), as previously mentioned, NIMBY-ism does not adequately explain local opposition to wind farms [74]. And, as previously stated, one's belief system is likely to foster acceptance or opposition towards wind farms. While some studies indicate a small shift in opinion to either more favorable or less favorable after actual wind farm construction, overall support for or against remain constant.

\section{THE EVALUATION PROCESS: A REAL-LIFE EXAMPLE}

I built an online HDM model and asked several participants who were identified as subject matter experts (SME) to test it. The sample size (participation) was small, but illustrated that the model could be extrapolated for a reallife example [75]. Out of 11 invitees, only three people 
participated: referred here as Participant A, Participant B, and Participant C ( 27\%).

Method of participation: An email was sent directing participants to the online HDM model. Attached to the email was a document outlining instructions on how to do the evaluation (Appendix A). The web site required students to create an account and log in. Once there, participants could choose from between four scenarios (as explained in the Scenarios section of this paper). Each scenario had its own separate link where participants could conduct their evaluations.

The project looks like this:

Scenario 1: Liberal Government + Booming Economy: Two participants

Scenario 2: Liberal Government + Recession: Two participants

Scenario 3: Conservative Government + Booming Economy: No participants

Scenario 4: Conservative Government + Recession: No participants

It should be noted that participants' individual areas of expertise were provided to me. I used this information to instruct participants on how to use the model. For example, if a participant's area of expertise was identified as being socioeconomic or environmental, participants were given the option of completing just that portion of the model. Of course I preferred that they try to evaluate the entire model, but I would accept their expert judgment on whatever part they chose to do. I gave participants the option of doing it this way, hoping to increase overall participation rates, since I assumed that everyone was busy. Unfortunately, this strategy did not increase participation rates.

For those participating, their individual areas of expertise are as follows: Participant A's areas of expertise were identified as the top level, all scenarios. Participant B's areas of expertise were identified as the top level, all scenarios. Participant C's areas of expertise were identified as environmental, all scenarios.

All three participants chose the first scenario, Liberal Government + Booming Economy. The following two tables labeled Figure 2 are the results of that evaluation.

The critical F-test value between subjects is .24. Using a lookup table and looking up $\mathrm{F}_{.01}$ with $(1,2)$ degrees of freedom, the value given in the table is 98.5, the same as the result for Scenario 1. Since this result equals the result in the lookup table, we would say that given this value, the F-value is likely to occur by chance with $\mathrm{p}<.01$. The same goes for the rest of the critical values in the table. For $F_{.025}$ with $(1,2)$ degrees of freedom, the critical $F$ value is 38.51 ; for $F_{.05}$ with $(1,2)$ degrees of freedom, the critical $F$ value is 18.51 ; and for $F_{0.1}$, the critical $F$ value is 8.53 . These all agree with the results in the lookup tables, respectively. Since this result equals the result in the lookup table, we would say that given this value, the F-value is likely to occur by chance with $p<$ .01 .

\begin{tabular}{|l|l|l|l|l|}
\hline Scenario 1 & Site 1 & Site 2 & Inconsistency \\
\hline Participant A & 0.45 & 0.55 & 0 \\
\hline Participant B & 0.47 & 0.53 & 0.01 \\
\hline Participant C & 0.54 & 0.46 & 0 \\
\hline Mean & 0.49 & 0.51 & \\
\hline Minimum & 0.45 & 0.46 & \\
\hline Maximum & 0.54 & $\mathbf{0 . 5 5}$ & \\
\hline Std. Deviation & $\mathbf{0 . 0 4}$ & $\mathbf{0 . 0 4}$ & \\
\hline Disagreement & & & $\mathbf{0 . 0 4}$ \\
\hline
\end{tabular}

\begin{tabular}{|l|c|c|c|c|}
\hline Source of Variation & Sum of Square & Deg. of freedom & Mean Square F-test value \\
\hline Between Subjects: & 0.00 & 1 & .001 & .24 \\
\hline Between Conditions: & 0.00 & 2 & 0.000 & \\
\hline Residual: & 0.01 & 2 & 0.004 & \\
\hline Total: & 0.01 & 5 & & \\
\hline Critical F-value with degrees of freedom 1 \& 2 at 0.01 level: & 98.5 \\
\hline Critical F-value with degrees of freedom 1 \& 2 at 0.025 level: & 38.51 \\
\hline Critical F-value with degrees of freedom 1 \& 2 at 0.05 level: & 18.51 \\
\hline Critical F-value with degrees of freedom 1 \& 2 at 0.1 level: & 8.53 \\
\hline
\end{tabular}

Figure 2: Results: Scenario 1 


\begin{tabular}{|l|l|l|l|l|}
\hline Scenario 2 & Site 1 & Site 2 & Inconsistency \\
\hline Participant B & 0.5 & 0.5 & 0 \\
\hline Participant A & 0.49 & 0.51 & 0 \\
\hline Mean & 0.5 & $\mathbf{0 . 5 1}$ & \\
\hline Minimum & $\mathbf{0 . 4 9}$ & $\mathbf{0 . 5}$ & \\
\hline Maximum & $\mathbf{0 . 5}$ & $\mathbf{0 . 5 1}$ & \\
\hline Std. Deviation & $\mathbf{0}$ & $\mathbf{0}$ & \\
\hline Disagreement & & & $\mathbf{0}$ \\
\hline
\end{tabular}

\begin{tabular}{|l|c|c|c|c|}
\hline Source of Variation & Sum of Square & Deg. of freedom & Mean Square & F-test value \\
\hline Between Subjects: & 0.00 & 1 & & 1 \\
\hline Between Conditions: & 0.00 & 1 & 0.000 & \\
\hline Residual: & 0.00 & 1 & 0.000 & \\
\hline Total: & 0.00 & 3 & & \\
\hline Critical F-value with degrees of freedom 1 \& 1 at 0.01 level: & 4052.18 \\
\hline Critical F-value with degrees of freedom 1 \& 1 at 0.025 level: & 647.79 \\
\hline Critical F-value with degrees of freedom 1 \& 1 at 0.05 level: & 161.45 \\
\hline Critical F-value with degrees of freedom 1 \& 1 at 0.1 level: & 39.86 \\
\hline
\end{tabular}

Figure 3: Results: Scenario 2

In the second scenario, only Participant A and Participant $B$ participated. The results indicate that there was no disagreement between the two. The near-perfect critical F-test value does not seem very likely; nevertheless that is the result. The rest of the $\mathrm{F}$ values do not vary from the expected values one would get from a critical $\mathrm{F}$ distribution lookup table. The results are interpreted like this: for $\mathrm{F}_{.01}(\mathrm{v} 1=1$ and $\mathrm{v} 2=1$ ) the lookup table indicates the critical $\mathrm{F}$ value is 4052.19. The actual results are 4052.18. Since this result equals the result in the lookup table, we would say that given this value, the F-value is likely to occur by chance with $\mathrm{p}<$ .01 . The rest of the critical $F$ values $-F_{.025}, F_{.05}$ and $F_{0.1}$ agree with this analysis given their critical F-test ratios.

Performing the evaluation: This section provides an example on how to evaluate the model.

Consider the scenario Conservative Government + Booming Economy. The first step in this analysis is to compare the objectives with the mission and rank them within each scenario. Next, compare the three objectives against each other. For example, if you choose to evaluate the scenario Conservative Government + Booming Economy, the evaluation would go as follows: select your panel of experts to do the evaluation. Preferably, at least one of these experts has a good understanding of the political climate when the evaluation is taking place. As previously stated, a conservative government likely would consider the impact to jobs over environmental impacts (theoretically, anyway). Whereas a liberal government might look for ways for the government to fund the site, a conservative government might prefer to leave the bulk of funding to corporations or private foundations. They might ease some restrictions on the permitting process, and so on.

For each pair of objectives, as it contributes to the mission, distribute 100 points between each comparison:

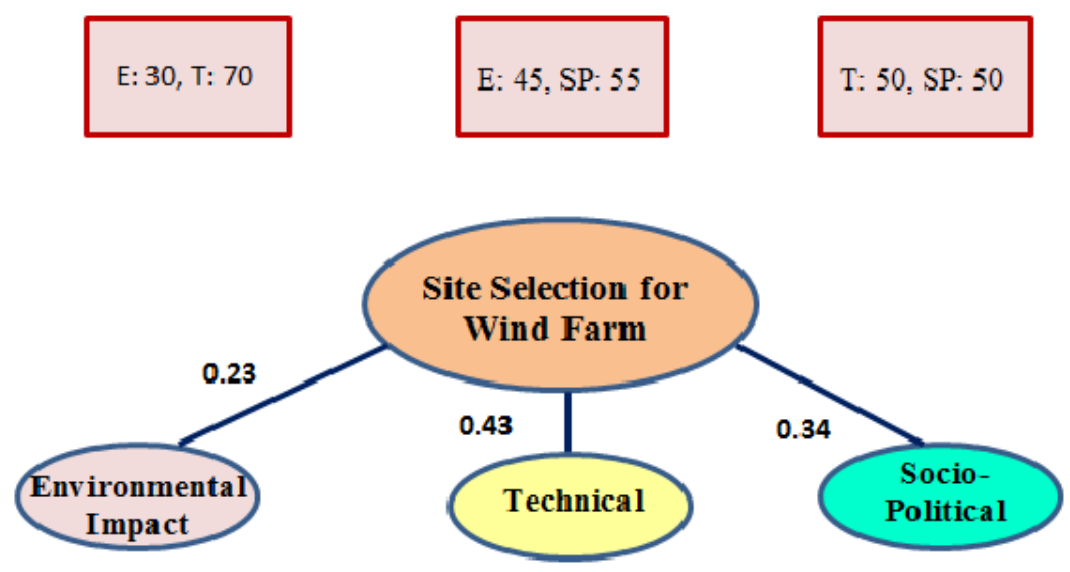

Figure 4: The Evaluation Process 
The pairwise comparison results between environmental impact, technical, and socio-political objectives are illustrated in the figure above.

The next step is to perform pairwise comparisons between the variables of the next level. For example, there are four variables under "Environmental Impact": impact to plant \& animal species [IPA], noise blades make [NO], proximity to urban centers and neighborhoods [PU], and visual impact [VZ]. Comparisons are made against each of the four variables under "Environmental Impact" and against each of the other four variables under the technical and socio-political objectives, respectively.

The pairwise comparison results between the 12 variables in the next level are illustrated in the following:

\section{$\begin{array}{llllllllllll}.05 & .05 & .04 & .04 & .12 & .16 & .18 & .12 & .05 & .11 & .04 & .04\end{array}$ \\ IPA NO PU VZ BA TL WR TS PR TX RB PA}

Figure 5: Results of Pairwise Comparison of 12 Variables

The next step in the analysis is to obtain the contribution to each goal of each of the 12 variables. This is obtained by multiplying each of the variables values by the relative values of the objectives. Start first with environmental impact and IPA, and so on:

$.23 * .05=.0115$;

$.23 * .04=.0092$;

$.23 * .18=.0414$;

$.23 * .11=.0253$;

$$
\begin{gathered}
.23 * .05=.0115 \\
.23 * .12=.0276 \\
.23 * .12=.0276 \\
.23 * .04=.0092
\end{gathered}
$$

$.23 * .04=.0092$

$.23 * .16=.0368$

$.23 * .05=.0115$;

$.23 * .04=.0092$

Next, obtain the contribution to each goal for the Technical objectives for each of the 12 variables:
$.43 * .05=.0215$
$.43 * .05=.0215$;
$.43 * .04=.0172$
$.43 * .12=.0512$;
$.43 * .18=.0774$
$.43 * .12=.0512$
$.43 * .11=.0473$
$.43 * .04=.0172$;
$.43 * .04=.0172$
$.43 * .16=.0688$
$.43 * .05=.0215$;
$.43 * .04=.0172$

Finally, obtain the contribution to each goal for the SocioPolitical objectives:

$\begin{array}{ll}.34 * .05=.017 ; & .34 * .05=.017 ; \\ .34 * .04=.0136 ; & .34 * .12=.0408 \\ .34 * .18=.0612 ; & .34 * .12=.0408 ; \\ .34 * .11=.0374 & \\ 34 * .04=.0136 & 34 * .04=.0136\end{array}$

Now, add the contributions of each goal together to obtain the relative value of each variable:

IPA: $.0115+.0215+.017=.05 ; \quad$ NO: $.0115+.0215+.017=.05$;

PU:.0092+.0172+.0136=.04; VZ: $.0092+.0172+.0136=.04$;

BA: $.0276+.0512+.0408=. \underline{1196} ; \quad$ TL: $.0368+.0688+.0544=. \underline{.16}$;

WR: $.0414+.0774+.0612=.18 ; \quad$ TS: $.0276+.0512+.0408=.1196$;

PR: $.0115+.0215+.017=.05 ; \quad$ TX: $.0253+.0473+.0374=.11$

RB: $.0092+.0172+.0136=.04 ; \quad$ PA: $.0092+.0172+.0136=.04$;

From observation, the variables are ranked in order of importance and then compared against the two possible wind sites. (Note: The first 5 are ranked. The rest tie for the least

important criteria, and are not necessary for our evaluation.)

1. WR (wind reliability): $=\underline{.18}$;

2. TL (transmission lines): $=. \underline{16}$;

3. TS (turbine size): and BA (battery/storage technologies) $=.1196$

4. $\mathbf{T X}(\operatorname{tax} /$ carbon credits $)=\underline{.11}$

The highest ranking criterion is WR, or wind reliability, followed by transmission lines, turbine size, and battery storage (tied), and tax and carbon credits.

Given our criteria of a conservative government but a booming economy, the site that aligns closely with the ranking is site 2 . The decision is based primarily on the fact that the site for the wind farm is bigger, and battery storage will be used. It is also determined that it is easier to deal with the migratory bird issue than it is to deal with the Native American burial ground close by. Although proximity to transmission lines comes in at second place, the fact that there is room for battery storage helps to mitigate the fact that the site sits slightly further away from transmission lines. Plus, given that the economy is booming, there is a greater likelihood of finding private funds to help deal with transmission issues. The carbon and tax credits ranks fairly high in this analysis, which indicates that the business plans to sell the carbon credits to help offset costs.

\section{CONCLUSION}

Using AHP or HDM in conjunction with scenarios is a useful methodology when making decisions using multiple criteria and within a given framework. This allows for both expert judgment and a quantitative approach to decisionmaking. The method I introduced in this paper allows for the consideration of socio-political factors, something that is often overlooked in the decision-making process.

The model is useful because the person or persons doing the analysis has the ability to tweak the framework to suit their analysis. For example, adding in an economic objective into the hierarchy makes sense, especially if that objective factors in with the overall analysis against other objectives in the hierarchy. Thus the model could be made as complex as the situation needs it to be.

The inclusion of scenarios based on the type of government in power at the time of proposal (liberal or conservative) allows for contingency planning that each type of governmental style introduces into the analysis. The example given in this paper of the wind farm in Boardman to which President Obama called a moratorium is but one example of why it is important to consider both political and governmental factors that should have been considered before the Chinese company tried to build near the Naval base. Perhaps, in this case, the outcome would have been the same regardless of the scenario in which it was evaluated. However, the fact that a prospective company must consider 
the governmental framework in which it evaluates the building of any wind farm should not be overlooked.

\section{FURTHER STUDY}

Further research using the model within a framework of siting methodology would continue to evaluate its usefulness, especially within a governmental framework. Also, further study on the impact of governmental ideology and its response to renewable energies like wind is warranted. While there is some research on government policy and its impact on renewable energy, not a lot of research looks into whether - or how -- party ideology impacts the funding, siting, and policy with regards to renewable energies like wind, but there is some suggestion that it does affect it, at least in the United States.

\section{REFERENCES}

[1] Oregon Department of Energy [Online]. Available: http://www.oregon.gov/energy/pages/about_us.aspx

[2] S. Tegen, M. Hand, et al. Technical Report, Cost of Wind Energy Review, TP-5000-52920 April 2012. Pgs. 5-8.

[3] Ida Kubiszewski and Cutler J. Cleveland. The Encyclopedia of the Earth, "Energy return on investment (EROI) for wind energy", June 7, 2007; updated March 4, 2013, http://www.eoearth.org/article/Energy_return_on_investment_(EROI)_ for_wind_energy\#gen8

[4] Thor D. Thorson, et al. Environmental Protection Agency, U.S. Forest Service, Natural Resources Conservation Services, Oregon NTURAL Heritage Program, and USGS. Ecoregions of Oregon, map. $\mathrm{ftp} / / / \mathrm{ftp}$.epa.gov/wed/ecoregions/or/or_front.pdf

[5] U.S. Department of Energy. National Renewable Energy Laboratory, June $6^{\text {th }}$, 2002. Oregon - Wind Power Resources Estimate, map. [Online].

Available: http://apps2.eere.energy.gov/wind/windexchange/pdfs/wind_maps/or_5 $0 \mathrm{~m} . \mathrm{pdf}$

[6] Elizabeth Harball and ClimateWire. Scientific American TM, "Floating Wind Turbines Coming to Oregon Coast", February 6, 2014. [Online]. Available: http://www.scientificamerican.com/article/floating-windturbines-coming-to-oregon-coast/

[7] Giorgio Corbetta et al. The European Wind Energy Association, The European offshore wind industry - key trends and statistics 2013, report, January 2014. [Online]. Available: http://www.ewea.org/fileadmin/files/library/publications/statistics/Euro pean_offshore_statistics_2013.pdf

[8] Oregon Department of Energy: Energy Facility Siting. Facility Siting Rules and Statues, [Online]. Available: http://www.oregon.gov/energy/Siting/Pages/rules.aspx

[9] Oregon Department of Energy: Energy Facility Siting. The Siting Process for Energy Facilities, [Online]. Available: http://www.oregon.gov/energy/Siting/Pages/process.aspx

[10] Oregon Department of Energy: Energy Facility Siting. Energy Facility Siting Standards, [Online]. Available: http://www.oregon.gov/energy/Siting/Pages/standards.aspx

[11] Oregon Department of Energy: Energy Facility Siting. About Oregon's Energy Facility Siting Council, Online]. Available: http://www.oregon.gov/ENERGY/Siting/Pages/sitehm.aspx

[12] United States Senate. Party Division in the Senate, 1789-Present, [Online].

Available: http://www.senate.gov/pagelayout/history/one_item_and_teasers/partyd iv.htm.

[13] U.S. House of Representatives. History, Art \& Archives, , Party Divisions of the House of Representatives, 1789-Present. http://history.house.gov/Institution/Party-Divisions/Party-Divisions/.
[14] Michael Matthews. Yahoo! Voices, Yahoo Contributor Network, June 3, 2006. Liberalism and Conservatism and Their Effect on Business in General, [Online]. Available: http://voices.yahoo.com/liberalismconservatism-their-effect-business- $41620 . \mathrm{html}$ ? cat $=9$.

[15] The Associated Press. Oregon Live, The Oregonian, September 28, 2012. "Obama blocks Chinese purchase of small Oregon wind farm project", article, [Online]. Available: http://www.oregonlive.com/environment/index.ssf/2012/09/oregon_win d_farm_purchase_by_c.html.

[16] Mike Francis. Oregon Live, The Oregonian, January 30 2013. "Chinese wind firm sues to void Oregon sale blocked by Obama for national security reasons," article, [Online]. Available: http://blog.oregonlive.com/oregonatwar/2013/01/chinese_wind_firm_s ues to void.html

[17] Author unknown. "Political Support Propels Renewable Energy," Solar Today, vol. 18 no. 4, pp. 22, 2004.

[18] Janet L. Sawin. "Mainstreaming Renewable Energy in the $21^{\text {st }}$ Century," State of the World Library, Worldwatch Paper 169, pp. 5-76, 2004.

[19] Neil Carter. "Greening the mainstream: party politics and the environment," Environmental Politics, vol. 22, no. 1, 2013.

[20] Diane P. Dupont and Ian J. Bateman. "Political Affiliation and Willingness to Pay: An Examination of the Nature of Benefits and Means of Provision," Ecological Economics, vol. 75, pp. 43-51, 2012.

[21] Richard Craig Crouch and Dorian S. Abbot. "Is Green Education Blue or Red? State-Level Environmental Education Program Development through the Lens of Red- and Blue-State Politics," The Journal of Environmental Education, vol. 40, no. 3, pp. 52-62, Spring 2009.

[22] Stephen Lacey. "What Are the Conservatives Big Ideas About Clean Energy," [Online]. Available: http://theenergycollective.com/stephenlacey/379196/where-areconservatives-big-ideas-about-clean-energy, May $15^{\text {th }}, 2014$, [Nov. 18, 2014].

[23] Ben Goldsmith and Toby Guise. The Conservative Environment Network, Ed. (February 2014). "Responsibility \& Resilience, What the Environment Means to Conservatives." [Online]. pp. 1-104. Available: https://dl.dropboxusercontent.com/u/36598516/CEN/CEN\%20Respons ibility\%20\%26\%20Resilience_Feb\%202014.pdf

[24] Claudia Hitaj. "Wind Power Development in the United States," Journal of Environmental Economics and Management, vol. 65, pp. 394-410, 2013.

[25] Oregon Department of Energy (ODOE). "Financial Considerations." [Online]. Available: http://www.oregon.gov/energy/RENEW/Pages/wind/Financial.aspx

[26] Vicki Norberg-Bohm. "Creating Incentives for Environmentally Enhancing Technological Change: Lessons From 30 Years of U.S. Energy Technology Policy," Technological Forecasting and Social Change, vol. 65, pp. 125-148, 2000.

[27] Jennifer E. Gardner and Ronald L. Lehr. "Enabling the Widespread Adoption of Wind Energy in the Western United States: the Case for Transmission, Operations and Market Reforms," Journal of Energy \& Natural Resources Law, vol. 31, no. 3, pp. 237-285, 2013.

[28] Ching, Kok Boon, et al. "Wind Farm Allocation In Malaysia Based On Multi-Criteria Decision Making Method", IEEE, pp. 1-6, 2011.

[29] Bing Wang, et al. "A decision model for energy resource selection in China," Energy Policy vol. 38, pp. 7130-7141, July 2010.

[30] Ilhan Talini. "A Holistic Approach for Wind Farm Site Selection by FAHP," Wind Farm - Technical Regulations, Potential Estimation and Siting Assessment. [Online]. pp. 213-214. July 2010. Available: www.intechopen.com

[31] R. Saidur, et al. "Environmental Impact of Wind Energy," Renewable and Sustainable Energy Reviews vol. 15, pp. 2423-2430, 2011.

[32] Dan Wilhelmsson, et al. "The Influence of offshore windpower on demersal fish," ICES Journal of Marine Science, vol. 63, pp. 775-784, 2006.

[33] Benjamin K. Sovacool. "Contextualizing avian mortality: A preliminary appraisal of bird and bat fatalities from wind, fossil-fuel, and nuclear energy," Energy Policy, vol. 37, pp. 2241-2248, 2009. 
[34] Taber D. Allison, et al. "Avian Issues for Offshore Wind Development," Marine Technology Society Journal, vol. 42, no. 2, pp. 28-38, Summer 2008.

[35] Brett K. Sandercock, Professor of Wildlife Biology, Division of Biology. "Effects of Wind Power Development on the Population Biology of Greater Prairie-Chicken in Kansas," Kansas State University, Manhattan, Kansas 66506, DE-EE0000526, May 22, 2013.

[36] Manuela de Lucas, et al. "Collision fatality of raptors in wind farms does not depend on raptor abundance," Journal of Applied Ecology, vol. 45, pp. 1695-1703, 2008.

[37] Jesper Madsen and David Boertmann. "Animal behavioral adaptation to changing landscapes: spring-staging geese habituate to wind farms," Landscape Ecol, vol. 23, pp. 1007-1011, 2008.

[38] Shannon Magari, et al. "Evaluation of community response to wind turbine-related noise in Western New York State," Noise and Health, pp.228-237, July-August 2014.

[39] Harvey H. Hubbard. "Aeroacoustics of large wind turbines," Journal of Acoustical Society of America, vol. 89, no. 6, pp. 2495-2508, June 1991.

[40] Malgorzata Pawlaczyk Luszcznska, et al. "Evaluation of Annoyance from the Wind Turbine Noise: A Pilot Study," International Journal of Occupational Medicine and Environmental Health, vol. 27, no. 3, pp. 364-388, 2014.

[41] Jeffery Swofford and Michael Slattery. "Public Attitudes of Wind Energy in Texas: Local Communities in Close Proximity to Wind Farms and Their Effect on Decision-Making," Energy Policy, vol. 38, pp. 2508-2519, 2010

[42] Maarten Wolsink. "Wind Power and the NIMBY-Myth: Institutional Capacity and the Limited Significance of Public Support," Renewable Energy, vol. 21, pp. 49-64, 2000.

[43] Maarten Wolsink. "Wind Power Implementation: The Nature of Public Attitudes: Equity and Fairness Instead of 'Backyard Motives'," Renewable and Sustainable Energy Reviews, vol. 11, pp. 1188-1207, 2007.

[44] Theocharis Tsoutsos, et al. "Visual impact evaluation of a wind park in a Greek island," Applied Energy, vol. 86, pp. 546-553, 2009.

[45] Justin Good. "The Aesthetics of Wind Energy," Human Ecology Review, vol. 13, no. 1, pp. 76-89, 2006.

[46] Ana del Carmen Torres Sibille, et al. "Development and Validation of a Multicriteria Indicator for the Assessment of Objective Aesthetic Impact of Wind Farms," Renewable and Sustainable Energy Reviews, vol. 33, pp. 40-66, 2009.

[47] D. Sutanto and W.R. Lachs. "Battery Energy Storage Systems for Sustainable Energy Development in Asia," Electric Power Systems Research, vol. 44, pp. 61-67, 1998.

[48] K. Yoshimoto, et al. "Analysis of Data Obtained in Demonstration Test about Battery Energy Storage System to Mitigate Output Fluctuation of Wind Farm," IEEE Power and Energy Society, pp. 1-5, Calgary 2009.

[49] Q. Li, et al. "On the Determination of Battery Energy Storage Capacity and Short-Term Power Dispatch of a Wind Farm," IEEE Transactions on Sustainable Energy, vol. 2, no. 2, pp. 148-158, April 2011.

[50] Florian Steinke, et al. "Grid vs. Storage in a 100\% Renewable Europe," Renewable Energy, vol. 50, pp. 826-832, 2013.

[51] Michaela Fürsch, et al. "The Role of Grid Extensions in a CostEfficient Transformation of the European Electricity System Until 2050," Applied Energy, vol. 104, pp. 642-652, 2013.

[52] John P. Daniel, et al. "National Offshore Wind Energy Grid Interconnection Study," Executive Summary, DOE Award No. EE0005365 , July $30^{\text {th }}, 2014$, pp. 1-241.

[53] Károly Tar and Sándor Szegedi. "Alterations of Potential Wind Energy with Height and Parts of the Day," Journal of Electrical \& Electronics Engineering, pp. 206-210, 1/2009.

[54] Nevzat Onat and Sedat Ersoz. "Analysis of wind climate and wind energy potential of regions in Turkey," Energy, vol. 36, pp. 148-156, 2011.
[55] M.R. Islam, et al. "Assessment of wind energy potentiality at Kudat and Labuan, Malaysia Using Weibull Distribution Function," Energy, vol. 36, pp. 985-992, 2011.

[56] Amy H. I. Lee, et al. "A Wind Turbine Evaluation Model under a Multi-Criteria Decision Making Environment," Energy Conversion and Management, vol. 64, pp. 289-300, 2012.

[57] Huajie Ding, et al. "Coordinated Operational Strategy of Energy Storage System and Wind Farm," 4th IEEE PES Innovative Smart Grid Technologies Europe (ISGT Europe), 2013, pp. 1-5.

[58] Leonardo P. Chamorro, et al. "Variable-Sized Wind Turbines Are a Possibility for Wind Farm Optimization," Wind Energy, vol. 17, pp. 1483-1494, 2014.

[59] Hector Rene Zamot et al. "Analysis of Wind Projects Considering Public Perception and Environmental Impact," National Science Foundation Award ECS- 0134021, University of Puerto RicoMayaguez, Mayaguez, PR 00681USA, published by IEEE, 2005, pp. 591-596.

[60] Tanja Mochler-Cieluch and Silvia Kodeih. "Mussel and Seaweed Cultivation in Offshore Wind Farms: An Opinion Survey," Coastal Management, vol. 36, pp. 392-411, 2008.

[61] Alastor M. Colbey. "Public Attitudes and Participation in Wind Turbine Development," Journal of Environmental Assessment Policy and Management, vol. 11, no. 1, pp. 69-95, March 2009.

[62] Yao Yin. "An Analysis of Empirical Cases of Community Wind in Oregon," Renewable and Sustainable Energy Reviews, vol. 17. pp. 5473, 2013.

[63] Yao Yin. "A Socio-Political Analysis of Policies and Incentives Applicable to Community Wind in Oregon," Energy Policy, vol. 42, pp. 442-449, 2012.

[64] Fredric C. Menz and Stephan Vachon. "The Effectiveness of Different Policy Regimes for Promoting Wind Power: Experiences from the States," Energy Policy, vol. 34, pp. 1786-1796, 2006.

[65] C.G. Dong. "Feed-in Tariff vs. Renewable Portfolio Standard: An Empirical Test of Their Relative Effectiveness in Promoting Wind Capacity Development," Energy Policy, vol. 42, pp. 476-485, 2012.

[66] Mhairi Aitken. "Why We Still Don't Understand the Social Aspects of Wind Power: A Critique of Key Assumptions within the Literature," Energy Policy, vol. 38, pp. 1834-1841, 2010.

[67] Dominic Spinelli. "Historic Preservation \& Offshore Wind Energy: Lessons Learned from the Cape Wind Saga," Gonzaga Law Review, vol. 46, no. 3, pp. 741-770, 2011.

[68] Kathleen Pickering and Benjamin Jewell. "Nature is Relative: Religious Affiliation, Environmental Attitudes, and Political Constraints on the Pine Ridge Indian Reservation," Journal for the Study of Religion, Nature and Culture, pp. 135-158, 2008.

[69] Euel Elliott, et al. "Political and Economic Determinants of Individuals' Support for Environmental Spending," Journal of Environmental Management, vol. 51, pp. 15-27, 1997.

[70] M. Niels Peterson and Jianguo Liu. "Impacts of Religion on Environmental Worldviews: The Teton Valley Case," Society \& Natural Resources: An International Journal, vol. 21, no. 8, pp. 704718, 15 August 2008.

[71] Kate K. Mulvaney, et al. "Different Shades of Green: A Case Study of Support for Wind Farms in the Rural Midwest," vol. 51, pp. 10121024,2013

[72] Sonari Glinton. "Indiana Flips From A Blue State To A Red One." Internet, http://www.npr.org/2012/11/07/164582508/indiana-flipsfrom-blue-to-red, Nov. 072012 [Nov. 16, 2014].

[73] Theresa M. Groth and Christine A. Vogt. "Rural Wind Farm Development: Social, Environmental and Economic Features Important to Local Residents," Renewable Energy, vol. 63, pp. 1-8, 2014.

[74] Charles R. Warren, et al. "'Green on Green': Public Perceptions of Wind Power in Ireland and Scotland," Journal of Environmental Planning and Management, vol. 48, no. 6, pp. 853-875, November 2005.

[75] Diane Yates. HDM model with four scenarios online analysis tool. http://research1.etm.pdx.edu/hdm2/ 
2015 Proceedings of PICMET '15: Management of the Technology Age

APPENDIX

TABLE 1: REFERENCES FOR THE HDM VARIABLES

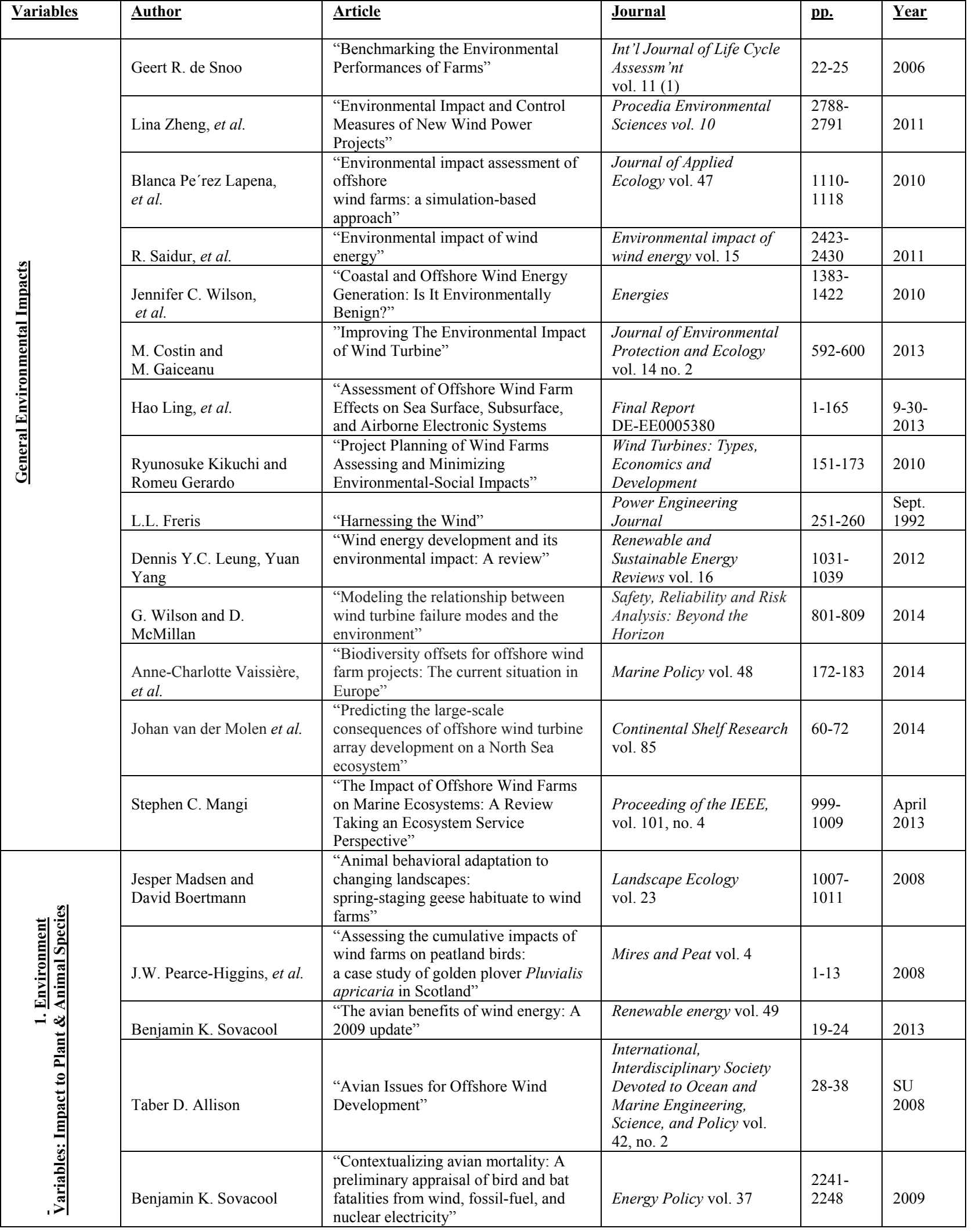


2015 Proceedings of PICMET '15: Management of the Technology Age

\begin{tabular}{|c|c|c|c|c|}
\hline Versar, Inc. & $\begin{array}{l}\text { "Spatially-Explicit Bat Impact } \\
\text { Screening Tool for Wind turbine } \\
\text { Setting" }\end{array}$ & $\begin{array}{l}\text { Prepared for: DOE EERE- } \\
\text { Wind \& Water Power } \\
\text { Program Topic Area 3: } \\
\text { Environmental Impact, } \\
\text { Risk Assessment } \\
\text { Framework to Identify } \\
\text { Siting Questions and } \\
\text { Solutions Related to } \\
\text { Wildlife and Habitat }\end{array}$ & $1-6$ & $\begin{array}{l}10-28- \\
2013\end{array}$ \\
\hline $\begin{array}{l}\text { Manuela de Lucas, } \\
\text { et al. }\end{array}$ & $\begin{array}{l}\text { "Collision fatality of raptors in wind } \\
\text { farms does not depend on raptor } \\
\text { abundance" }\end{array}$ & $\begin{array}{l}\text { Journal of } \\
\text { Applied Ecology } \\
\text { vol. } 45\end{array}$ & $\begin{array}{l}1698- \\
1703\end{array}$ & 2008 \\
\hline Brett K. Sandercock & $\begin{array}{l}\text { "Environmental Impacts of Wind } \\
\text { Power Development on the Population } \\
\text { Biology of Greater Prairie-Chickens" }\end{array}$ & $\begin{array}{l}\text { Final Technical Report } \\
\text { DOE Award Number: } \\
\text { DE-EE0000526 } \\
\text { Project Period: } \\
\text { 12/01/2009_06/22/2012 } \\
\end{array}$ & $1-62$ & $\begin{array}{l}22 \text { May } \\
2013\end{array}$ \\
\hline Donata Kurpas, et al. & Health Impact of Wind Farms" & $\begin{array}{l}\text { Annals of Agricultural and } \\
\text { Environmental Medicine } \\
\text { vol. } 20 \text {, } \\
\text { no. } 3\end{array}$ & $595-605$ & 2013 \\
\hline Jeff P. Cohn & "How Ecofriendly Are Wind Farms?" & Bioscience vol. 58 , no. 7 & $576-578$ & $\begin{array}{l}\text { July/ } \\
\text { Aug. } \\
2008\end{array}$ \\
\hline $\begin{array}{l}\text { Dan Wilhelmsson, } \\
\text { et al. }\end{array}$ & $\begin{array}{l}\text { "The influence of offshore windpower } \\
\text { on demersal fish" }\end{array}$ & $\begin{array}{l}\text { ICES Journal of Marine } \\
\text { Science }\end{array}$ & $775-584$ & 2006 \\
\hline $\begin{array}{l}\text { Martina Carrete, } \\
\text { et al. }\end{array}$ & $\begin{array}{l}\text { "Mortality at wind-farms is positively } \\
\text { related to large-scale distribution and } \\
\text { aggregation in griffon vultures" }\end{array}$ & $\begin{array}{l}\text { Biological Conservation } \\
\text { vol. } 145\end{array}$ & $102-108$ & 2012 \\
\hline MaartenWolsink & $\begin{array}{l}\text { "Near-shore wind power-Protected } \\
\text { seascapes, environmentalists' attitudes, } \\
\text { and the technocratic planning } \\
\text { perspective" }\end{array}$ & $\begin{array}{l}\text { Land Use Policy } \\
\text { vol. } 28\end{array}$ & $195-203$ & 2010 \\
\hline $\begin{array}{l}\text { Jonas Teilmann and Jacob } \\
\text { Carstensen }\end{array}$ & $\begin{array}{l}\text { "Negative long term effects on harbor } \\
\text { porpoises from a large scale offshore } \\
\text { wind farm in the Baltic-evidence of } \\
\text { slow recovery" }\end{array}$ & $\begin{array}{l}\text { Environmental Research } \\
\text { Letters } \\
\text { Vol. } 7\end{array}$ & $1-10$ & 2012 \\
\hline $\begin{array}{l}\text { Espen Lie Dahl, } \\
\text { et al. }\end{array}$ & $\begin{array}{l}\text { "Reduced breeding success in white- } \\
\text { tailed eagles at Smøla windfarm, } \\
\text { western Norway, is caused by mortality } \\
\text { and displacement" }\end{array}$ & $\begin{array}{l}\text { Biological Conservation } \\
\text { vol. } 145\end{array}$ & $79-85$ & 2012 \\
\hline $\begin{array}{l}\text { National Wind Technology } \\
\text { Center }\end{array}$ & $\begin{array}{l}\text { "Reducing Bat Fatalities From } \\
\text { Interactions with Operating Wind } \\
\text { Turbines" }\end{array}$ & Internet: www.nrel.gov & $1-2$ & $\begin{array}{l}\text { Nov. } \\
2013\end{array}$ \\
\hline Oliver Krüger & $\begin{array}{l}\text { "The return of the white-tailed eagle } \\
\text { (Haliaeetus albicilla) to northern } \\
\text { Germany: Modelling the past to predict } \\
\text { the future" }\end{array}$ & $\begin{array}{l}\text { Biological Conservation } \\
\text { vol. } 143\end{array}$ & $710-721$ & 2010 \\
\hline Dimitris Al. Katsaprakakis & $\begin{array}{l}\text { "A review of the environmental and } \\
\text { human impacts from wind parks. } \\
\text { A case study for the Prefecture of } \\
\text { Lasithi, Crete" }\end{array}$ & $\begin{array}{l}\text { Renewable and } \\
\text { Sustainable Energy } \\
\text { Reviews vol. } 16\end{array}$ & $\begin{array}{l}2850- \\
2863\end{array}$ & 2012 \\
\hline M. van Deurs, et al. & $\begin{array}{l}\text { "Short- and long-term effects of an } \\
\text { offshore wind farm } \\
\text { on three species of sandeel and their } \\
\text { sand habitat" }\end{array}$ & $\begin{array}{l}\text { Marine Ecology Progress } \\
\text { Series } \\
\text { Vol. } 458\end{array}$ & $169-180$ & 2012 \\
\hline Luis Tapia, et al. & $\begin{array}{l}\text { "Using probability of occurrence to } \\
\text { assess potential } \\
\text { interaction between wind farms and a } \\
\text { residual } \\
\text { population of golden eagle Aquila } \\
\text { chrysaetos in NW Spain" }\end{array}$ & $\begin{array}{l}\text { Biodiversity Conservation } \\
\text { vol. } 18\end{array}$ & $\begin{array}{l}2033- \\
2041\end{array}$ & 2009 \\
\hline $\begin{array}{l}\text { Rafael Villegas-Patraca, et } \\
\text { al. }\end{array}$ & $\begin{array}{l}\text { "Scavenger removal: Bird and bat } \\
\text { carcass persistence in a tropical wind } \\
\text { farm" }\end{array}$ & Acta Oecologica & $121-125$ & 2012 \\
\hline $\begin{array}{l}\text { Christian C. Voigt, } \\
\text { et al. }\end{array}$ & $\begin{array}{l}\text { "The catchment area of wind farms for } \\
\text { European bats: A plea for international } \\
\text { regulations" }\end{array}$ & $\begin{array}{l}\text { Biological Conservation } \\
\text { vol. } 153\end{array}$ & $80-86$ & 2012 \\
\hline
\end{tabular}


2015 Proceedings of PICMET '15: Management of the Technology Age

\begin{tabular}{|c|c|c|c|c|c|}
\hline & T. Campedelli, et al. & $\begin{array}{l}\text { "Raptor displacement due to the } \\
\text { construction of a wind } \\
\text { farm: preliminary results after the first } \\
2 \text { years since the } \\
\text { construction" }\end{array}$ & $\begin{array}{l}\text { Ethology Ecology \& } \\
\text { Evolution vol. } 26, \\
\text { no. } 4\end{array}$ & $376-391$ & 2014 \\
\hline & Thomas A. Wilding & $\begin{array}{l}\text { "Effects of man-made structures on } \\
\text { sedimentary oxygenation: Extent, } \\
\text { seasonality and implications for } \\
\text { offshore renewables" }\end{array}$ & $\begin{array}{l}\text { Marine Environmental } \\
\text { Research vol. } 97\end{array}$ & $39-47$ & 2014 \\
\hline & Sabine Müller, et al. & $\begin{array}{l}\text { "Evaluation of immune and stress } \\
\text { status in harbour porpoises (Phocoena } \\
\text { phocoena): can hormones and mRNA } \\
\text { expression levels serve as indicators to } \\
\text { assess stress?" }\end{array}$ & $\begin{array}{l}B M C \text { Veterinary Research } \\
\text { vol. } 9 \\
\text { no. } 145\end{array}$ & $1-11$ & 2013 \\
\hline & $\begin{array}{l}\text { Hsiang-Chih Chan, } \\
\text { et al. }\end{array}$ & $\begin{array}{l}\text { "Preliminary plan of underwater } \\
\text { environmental } \\
\text { monitoring in the offshore wind farm } \\
\text { in the western } \\
\text { sea of Taiwan" }\end{array}$ & IEEE Transactions & $1-4$ & 2013 \\
\hline \multirow{16}{*}{ 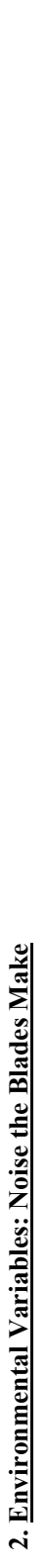 } & $\begin{array}{l}\text { Harvey H. Hubbard and } \\
\text { Kevin P. Shepherd }\end{array}$ & "Aeroacoustics of large wind turbines" & $\begin{array}{l}\text { Journal Acoustical Society } \\
\text { of America, vol. } 89 \text { no. } 6\end{array}$ & $\begin{array}{l}2495- \\
2508\end{array}$ & $\begin{array}{l}\text { June } \\
1991\end{array}$ \\
\hline & E.A. King, et al. & $\begin{array}{l}\text { "Assessing noise from wind farm } \\
\text { developments in Ireland: A } \\
\text { consideration of critical wind speeds } \\
\text { and turbine choice" }\end{array}$ & Energy Policy, vol. 41 & $548-560$ & 2012 \\
\hline & $\begin{array}{l}\text { George C. Greene and } \\
\text { Harvey H. Hubbard }\end{array}$ & $\begin{array}{l}\text { "Some Calculated Effects of Non- } \\
\text { Uniform Inflow on the Radiated Noise } \\
\text { of a Large Wind Turbine" }\end{array}$ & $\begin{array}{l}\text { NASA Technical } \\
\text { Memorandum } 81813 \\
\text { (unclassified) }\end{array}$ & $1-12$ & $\begin{array}{l}\text { May } \\
1980\end{array}$ \\
\hline & $\begin{array}{l}\text { George C. Greene and } \\
\text { Harvey H. Hubbard }\end{array}$ & $\begin{array}{l}\text { "Environmental Noise Characteristics } \\
\text { of the Mod- } 5 \text { B ( } 3.2 \mathrm{MW}) \text { Wind } \\
\text { Turbine Generator" }\end{array}$ & $\begin{array}{l}\text { NASA Technical } \\
\text { Memorandum } 101567 \\
\text { (unclassified) }\end{array}$ & $1-27$ & $\begin{array}{l}\text { March } \\
1989\end{array}$ \\
\hline & Yu-Chen Chang, et al. & $\begin{array}{l}\text { "Study and Application of Underwater } \\
\text { Noise Impact in Coastal Region of } \\
\text { Coastal Western Taiwan" }\end{array}$ & $\begin{array}{l}\text { Journal of Computational } \\
\text { Acoustics, vol. 22, } \\
\text { no. } 1\end{array}$ & $1-14$ & 2014 \\
\hline & $\begin{array}{l}\text { Shannon Magari, } \\
\text { et al. }\end{array}$ & $\begin{array}{l}\text { "Evaluation of community response to } \\
\text { wind turbine-related noise in Western } \\
\text { New York State" }\end{array}$ & $\begin{array}{l}\text { Noise and Health } \\
\text { vol. } 17, \text { no. } 21\end{array}$ & $1-9$ & $\begin{array}{l}\text { Nov. } 5 \\
2014 \\
\end{array}$ \\
\hline & $\begin{array}{l}\text { Kevin P. Shepherd, } \\
\text { et al. }\end{array}$ & $\begin{array}{l}\text { "Evaluation of Human Exposure to the } \\
\text { Noise from Large Wind Turbine } \\
\text { Generators" }\end{array}$ & $\begin{array}{l}\text { Noise Control Engineering } \\
\text { Journal } \\
\text { vol. } 21\end{array}$ & $30-37$ & $\begin{array}{l}\text { Jul-Aug } \\
1983\end{array}$ \\
\hline & Kim Dirks, et al. & $\begin{array}{l}\text { "Evaluating the impact of wind turbine } \\
\text { noise on health-related quality of life" }\end{array}$ & $\begin{array}{l}\text { Noise and Health } \\
\text { vol. } 13 \text {, no. } 54\end{array}$ & $1-8$ & $\begin{array}{l}\text { Sept.- } \\
\text { Oct. } \\
2011 \\
\end{array}$ \\
\hline & $\begin{array}{l}\text { Malgorzata Pawlaczyk- } \\
\text { Luszczynska, et al. }\end{array}$ & $\begin{array}{l}\text { "Evaluation of Annoyance from the } \\
\text { Wind Turbine Noise: A Pilot Study" }\end{array}$ & $\begin{array}{l}\text { International Journal of } \\
\text { Occupational Medicine } \\
\text { and Environmental Health } \\
\text { vol. } 27, \text { no. } 3\end{array}$ & $364-388$ & 2014 \\
\hline & $\begin{array}{l}\text { David G. Stephens, } \\
\text { et al. }\end{array}$ & $\begin{array}{l}\text { "Guide to the Evaluation of Human } \\
\text { Exposure to Noise from Large Wind } \\
\text { Turbines" }\end{array}$ & $\begin{array}{l}\text { NASA Technical } \\
\text { Memorandum } 83288 \\
\text { (unclassified) }\end{array}$ & $1-63$ & $\begin{array}{l}\text { March } \\
1982 \\
\end{array}$ \\
\hline & $\begin{array}{l}\text { Henrik Møller and } \\
\text { Christian Sejer Pedersen }\end{array}$ & $\begin{array}{l}\text { "Low-frequency noise from large wind } \\
\text { turbines" }\end{array}$ & $\begin{array}{l}\text { Journal Acoustical Society } \\
\text { of America, vol. } 129 \text { no. } 6\end{array}$ & $\begin{array}{l}3727- \\
3744 \\
\end{array}$ & $\begin{array}{l}\text { June } \\
2011\end{array}$ \\
\hline & Larry A. Viterna & $\begin{array}{l}\text { "Method for Predicting } \\
\text { Impulsive Noise Generated by } \\
\text { Wind Turbine Rotors" }\end{array}$ & $\begin{array}{l}1982 \text { International } \\
\text { Conference on Noise } \\
\text { Engineering, S.F., CA. }\end{array}$ & $1-4$ & $\begin{array}{l}\text { May 17- } \\
18 \\
1982 \\
\end{array}$ \\
\hline & $\begin{array}{l}\text { Daniel Shepherd and Rex } \\
\text { Billington }\end{array}$ & $\begin{array}{l}\text { "Mitigating the Acoustic Impacts of } \\
\text { Modern Technologies: Acoustic, } \\
\text { Health, and Psychosocial Factors } \\
\text { Informing Wind Farm Placement" }\end{array}$ & $\begin{array}{l}\text { Bulletin of Science } \\
\text { Technology \& Society }\end{array}$ & $389-398$ & $\begin{array}{l}\text { Aug. 22, } \\
2011\end{array}$ \\
\hline & J.K. Kaldellis, et al. & $\begin{array}{l}\text { "Noise impact assessment on the basis } \\
\text { of onsite acoustic noise immission } \\
\text { measurements for a representative } \\
\text { wind farm" }\end{array}$ & $\begin{array}{l}\text { Renewable energy } \\
\text { vol. } 41\end{array}$ & $306-318$ & 2012 \\
\hline & Arline L. Bronzaft & $\begin{array}{l}\text { "The Noise From Wind Turbines: } \\
\text { Potential Adverse Impacts on } \\
\text { Children's Well-Being" }\end{array}$ & $\begin{array}{l}\text { Bulletin of Science } \\
\text { Technology \& Society } \\
\text { vol. } 31\end{array}$ & $291-295$ & $\begin{array}{l}\text { July 19, } \\
2011\end{array}$ \\
\hline & & "The Audubon Cause: Energy: & & & \\
\hline
\end{tabular}


2015 Proceedings of PICMET '15: Management of the Technology Age

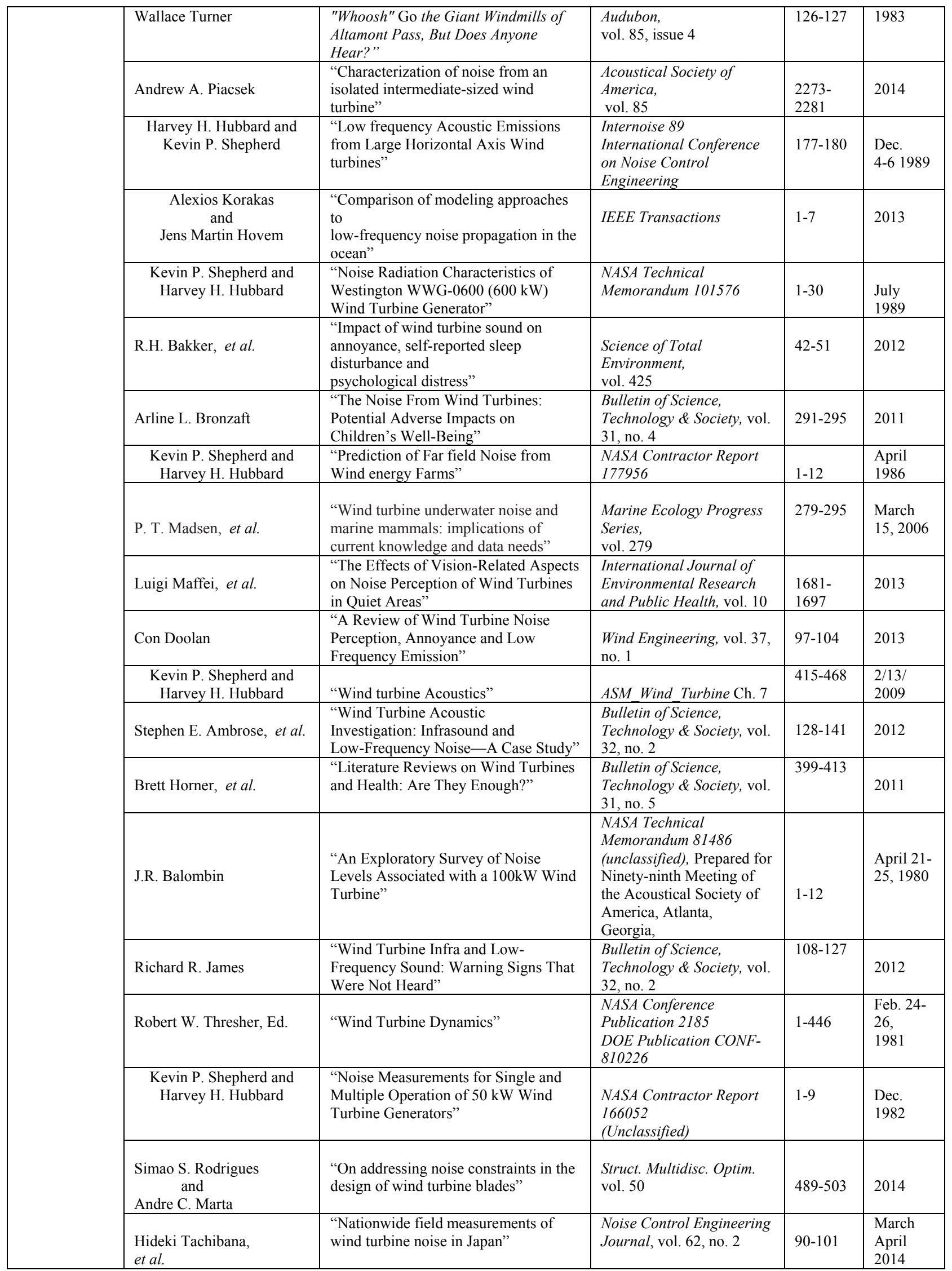


2015 Proceedings of PICMET '15: Management of the Technology Age

\begin{tabular}{|c|c|c|c|c|c|}
\hline \multirow{10}{*}{  } & Piers Wehner & "Backyard Blues" & $\begin{array}{l}\text { Estates Gazette, } \\
\text { Issue } 725\end{array}$ & 110 & $\begin{array}{l}\text { June } \\
2007\end{array}$ \\
\hline & $\begin{array}{l}\text { Jeffrey Swofford and } \\
\text { Michael Slattery }\end{array}$ & $\begin{array}{l}\text { "Public attitudes of wind energy in } \\
\text { Texas: Local communities in close } \\
\text { proximity to wind farms and their } \\
\text { effect on decision-making" }\end{array}$ & $\begin{array}{l}\text { Energy Policy } \\
\text { vol. } 38\end{array}$ & $\begin{array}{l}2508- \\
2519\end{array}$ & 2010 \\
\hline & Donata Kurpas, et al. & "Health impact of wind farms" & $\begin{array}{l}\text { Annals of Agricultural and } \\
\text { Environmental Medicine, } \\
\text { vol. 20, } \\
\text { no. } 3\end{array}$ & $595-605$ & 2013 \\
\hline & Corey Lang, et al. & $\begin{array}{l}\text { "The windy city: Property value } \\
\text { impacts of wind turbines in an } \\
\text { urban setting" }\end{array}$ & $\begin{array}{l}\text { Energy Economics, } \\
\text { vol. } 44\end{array}$ & $413-421$ & 2014 \\
\hline & $\begin{array}{l}\text { Jeffrey Swofford and } \\
\text { Michael Slattery }\end{array}$ & $\begin{array}{l}\text { "Public attitudes of wind energy in } \\
\text { Texas: Local communities in close } \\
\text { proximity to wind farms and their } \\
\text { effect on decision-making" }\end{array}$ & Energy Policy, vol. 38 & $\begin{array}{l}2508- \\
2519\end{array}$ & 2010 \\
\hline & Maarten Wolsink & $\begin{array}{l}\text { "Wind power implementation: The } \\
\text { nature of public attitudes: Equity and } \\
\text { fairness instead } \\
\text { of "backyard motives"" }\end{array}$ & $\begin{array}{l}\text { Renewable and } \\
\text { Sustainable Energy } \\
\text { Reviews, vol. } 11\end{array}$ & $\begin{array}{l}1188- \\
1207\end{array}$ & 2007 \\
\hline & $\begin{array}{l}\text { Christopher R. Jones and } \\
\text { J. Richard Eiser }\end{array}$ & $\begin{array}{l}\text { "Understanding 'local' opposition to } \\
\text { wind development in the UK: How big } \\
\text { is a backyard?" }\end{array}$ & Energy Policy, vol. 38 & $\begin{array}{l}3106- \\
3117\end{array}$ & 2010 \\
\hline & $\begin{array}{l}\text { Lawrence J. Dykman } \\
\text { U.S. Gov't. Accountability } \\
\text { Office }\end{array}$ & $\begin{array}{l}\text { "Wind Power's Contribution to } \\
\text { Electric Power Generation and } \\
\text { Impact on Farms and Rural } \\
\text { Communities" }\end{array}$ & Renewable Energy & $1-107$ & $\begin{array}{l}\text { Sept. } \\
2004\end{array}$ \\
\hline & Maarten Wolsink & $\begin{array}{l}\text { "Wind power and the NIMBY-myth: } \\
\text { institutional capacity and the limited } \\
\text { significance of public support" }\end{array}$ & $\begin{array}{l}\text { Renewable Energy } \\
\text { vol. } 21\end{array}$ & $49-64$ & 2000 \\
\hline & Gil Bohrer, et al. & $\begin{array}{l}\text { "Optimizing Wind Power Generation } \\
\text { while Minimizing } \\
\text { Wildlife Impacts in an Urban Area" }\end{array}$ & $\begin{array}{l}P L O S O N \\
\text { vol. } 8, \text { issue } 2\end{array}$ & $1-8$ & $\begin{array}{l}\text { Feb. } \\
2013\end{array}$ \\
\hline \multirow{11}{*}{ 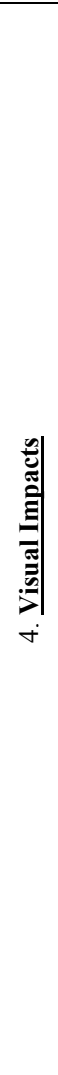 } & Justin Good & "The Aesthetics of Wind Energy" & $\begin{array}{l}\text { Human Ecology Review, } \\
\text { vol. } 13, \text { no. } 1\end{array}$ & 76-89 & 2006 \\
\hline & $\begin{array}{l}\text { Ana del Carmen Torres } \\
\text { Sibille, et al. }\end{array}$ & $\begin{array}{l}\text { "Development and validation of a } \\
\text { multicriteria indicator for the } \\
\text { assessment of objective aesthetic } \\
\text { impact of wind frms" }\end{array}$ & $\begin{array}{l}\text { Renewable and } \\
\text { Sustainable Energy } \\
\text { Reviews, vol. } 13\end{array}$ & $40-66$ & 2009 \\
\hline & $\begin{array}{l}\text { Jeffrey Swofford and } \\
\text { Michael Slattery }\end{array}$ & $\begin{array}{l}\text { "Public attitudes of wind energy in } \\
\text { Texas: Local communities in close } \\
\text { proximity to wind farms and their } \\
\text { effect on decision-making }\end{array}$ & Energy Policy vol. 38 & $\begin{array}{l}2508- \\
2519\end{array}$ & 2010 \\
\hline & Bernd Möller & $\begin{array}{l}\text { "Changing wind-power landscapes: } \\
\text { regional assessment of visual impact on } \\
\text { land use and population in } \\
\text { Northern Jutland, Denmark" }\end{array}$ & $\begin{array}{l}\text { Applied Energy, } \\
\text { vol. } 83\end{array}$ & $477-494$ & $\begin{array}{l}\text { April 9, } \\
2005\end{array}$ \\
\hline & $\begin{array}{l}\text { Jonas Abromas and Júrate } \\
\text { Kamicaitytè-Virbasiené }\end{array}$ & $\begin{array}{l}\text { "Problems of Determining Size and } \\
\text { Character of Wind Turbines' Visual } \\
\text { Impact Zones on Lithuanian } \\
\text { Landscape" }\end{array}$ & $\begin{array}{l}\text { Environmental Research, } \\
\text { Engineering and } \\
\text { Management vol. } 62, \text { no. } 4\end{array}$ & $21-29$ & $\begin{array}{l}\text { Sept. } \\
2012\end{array}$ \\
\hline & $\begin{array}{l}\text { Douglas C. Eltham, } \\
\text { et al. }\end{array}$ & $\begin{array}{l}\text { "Change in public attitudes towards a } \\
\text { Cornish wind farm: } \\
\text { Implications for planning" }\end{array}$ & Energy Policy, vol. 36 & $23-33$ & 2008 \\
\hline & $\begin{array}{l}\text { Theocharis Tsoutsos, } \\
\text { et al. }\end{array}$ & $\begin{array}{l}\text { "Visual impact evaluation of a wind } \\
\text { park in a Greek island" }\end{array}$ & $\begin{array}{l}\text { Applied Energy, } \\
\text { vol. } 86\end{array}$ & $546-553$ & 2009 \\
\hline & Jacob Ladenburg & $\begin{array}{l}\text { "Visual impact assessment of offshore } \\
\text { wind farms and prior experience" }\end{array}$ & $\begin{array}{l}\text { Applied Energy, } \\
\text { vol. } 86\end{array}$ & $380-387$ & 2009 \\
\hline & Juan Pablo Hurtado, et al. & $\begin{array}{l}\text { "Spanish method of visual impact } \\
\text { evaluation in wind farms" }\end{array}$ & $\begin{array}{l}\text { Renewable and } \\
\text { Sustainable Energy } \\
\text { Reviews vol. } 8\end{array}$ & $483-491$ & 2004 \\
\hline & $\begin{array}{l}\text { Jacob Ladenburg and Alex } \\
\text { Dubgaard }\end{array}$ & $\begin{array}{l}\text { "Willingness to pay for reduced visual } \\
\text { disamenities } \\
\text { from offshore wind farms in Denmark" }\end{array}$ & Energy Policy vol. 35 & $\begin{array}{l}4059- \\
4071\end{array}$ & 2007 \\
\hline & Ivan Urlaub & "High Stakes in the South" & $\begin{array}{l}\text { Energy Policy News, vol. } \\
20, \text { issue } 5\end{array}$ & $20-20$ & 2006 \\
\hline
\end{tabular}


2015 Proceedings of PICMET '15: Management of the Technology Age

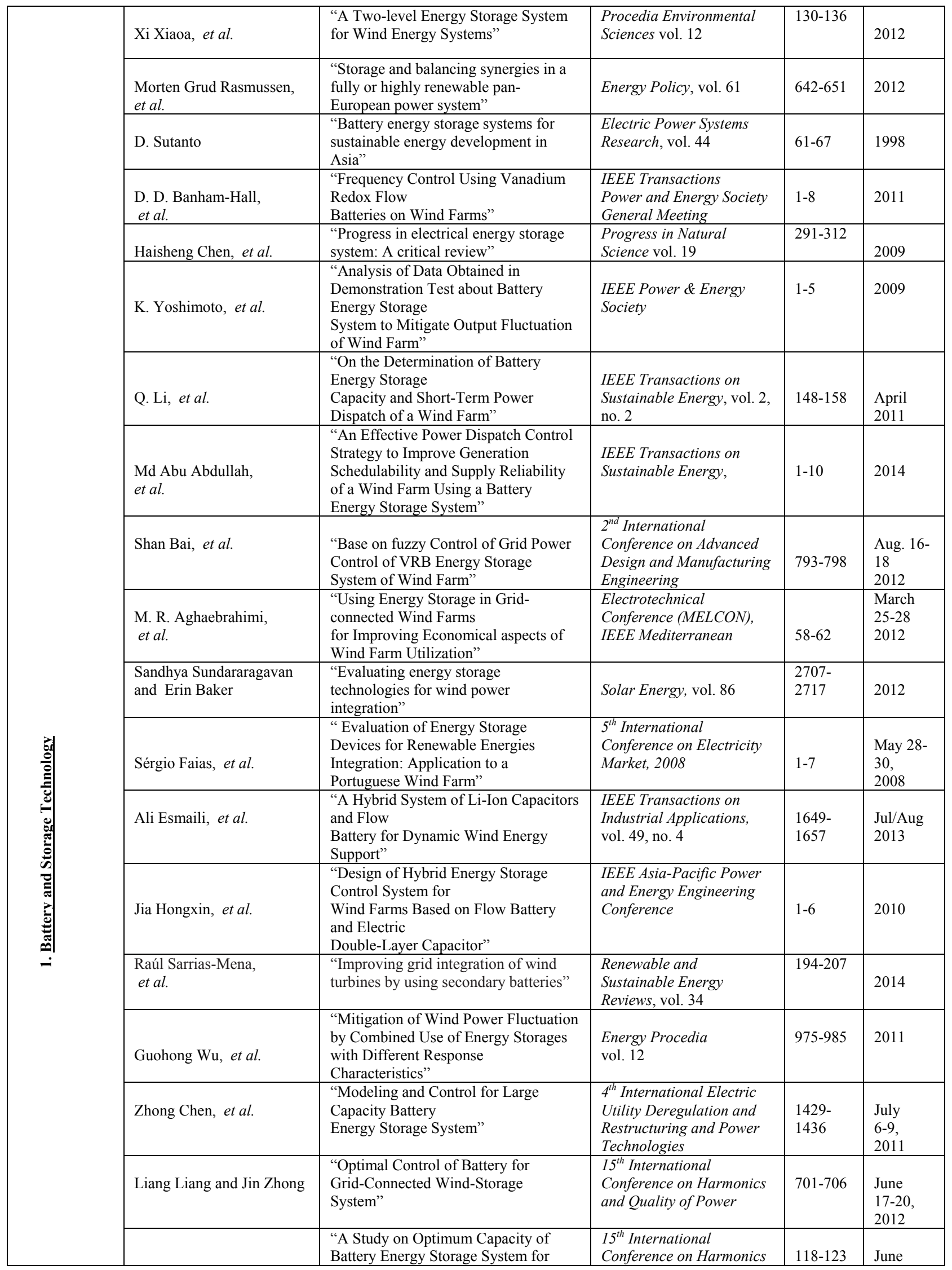


2015 Proceedings of PICMET '15: Management of the Technology Age

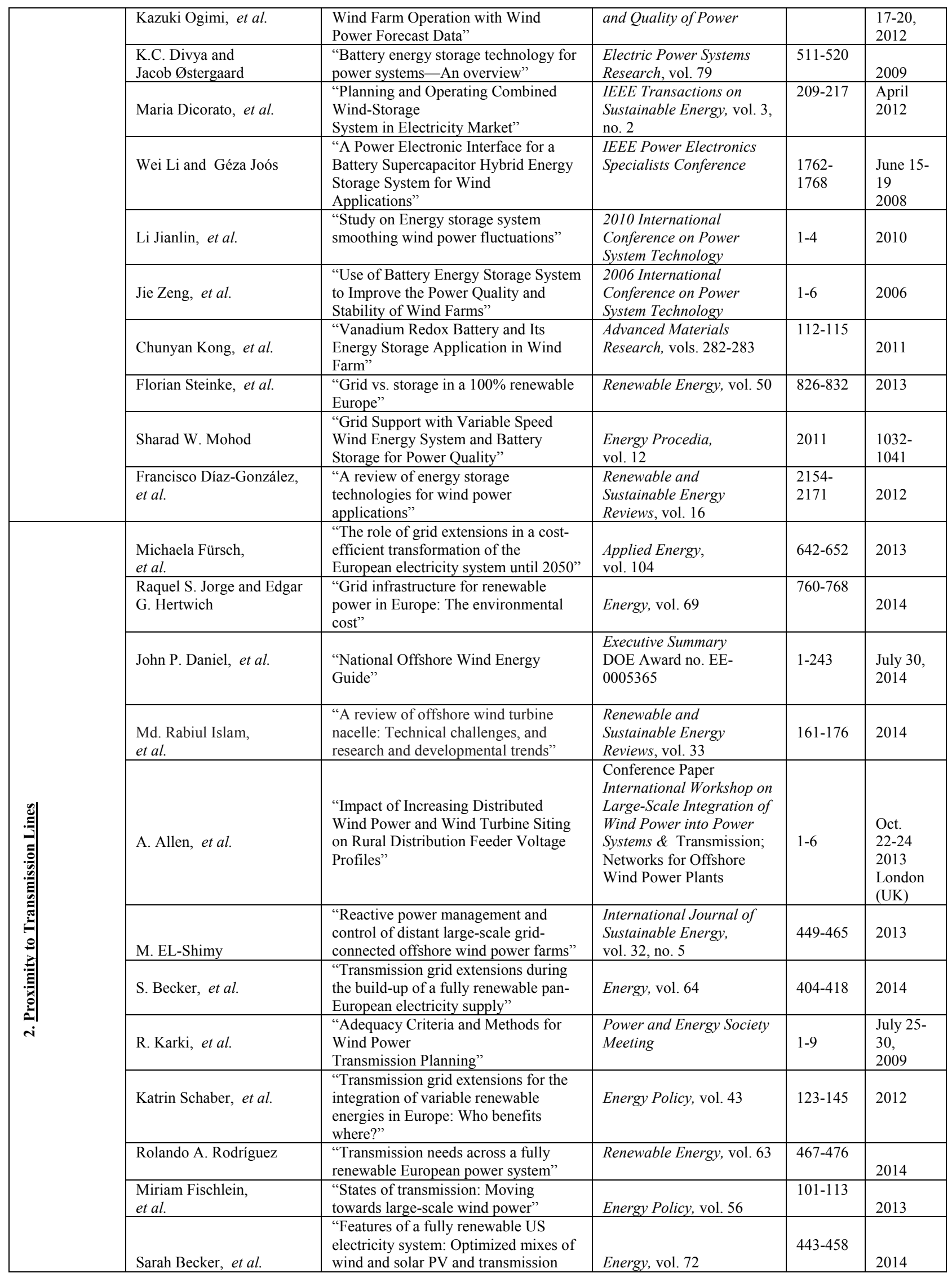


2015 Proceedings of PICMET '15: Management of the Technology Age

\begin{tabular}{|c|c|c|c|c|c|}
\hline & & grid extensions" & & & \\
\hline & $\begin{array}{l}\text { Rodolfo Araneo and } \\
\text { Chiara Vergine }\end{array}$ & $\begin{array}{l}\text { "Low-Environmental Impact Routeing } \\
\text { of Overhead } \\
\text { Power Lines for the Connection of } \\
\text { Renewable } \\
\text { Energy Plants to the Italian HV Grid" }\end{array}$ & $\begin{array}{l}\text { IEEE } 14^{\text {th }} \text { International } \\
\text { Conference on } \\
\text { Environment and } \\
\text { Electrical Engineering }\end{array}$ & $386-391$ & $\begin{array}{l}\text { May } 10- \\
12,2014 \\
\text { Krakow }\end{array}$ \\
\hline & $\begin{array}{l}\text { Rehana Perveen, } \\
\text { et al. }\end{array}$ & $\begin{array}{l}\text { "Off-shore wind farm development: } \\
\text { Present status and challenges" }\end{array}$ & $\begin{array}{l}\text { Renewable and } \\
\text { Sustainable Energy } \\
\text { Reviews, vol. } 29 \\
\end{array}$ & $780-792$ & 2014 \\
\hline \multirow{18}{*}{ 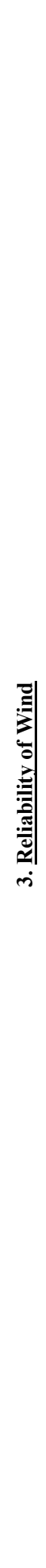 } & $\begin{array}{l}\text { Y. Gao and } \\
\text { R. Billinton }\end{array}$ & $\begin{array}{l}\text { "Adequacy assessment of generating } \\
\text { systems containing wind power } \\
\text { considering wind speed correlation" }\end{array}$ & $\begin{array}{l}\text { IET Renewable Power } \\
\text { Generation, vol. 3, issue } 2\end{array}$ & $217-226$ & 2009 \\
\hline & $\begin{array}{l}\text { Károly Tar } \\
\text { and } \\
\text { Sándor Szegedi }\end{array}$ & $\begin{array}{l}\text { "Alterations of potential wind energy } \\
\text { with height and parts of the day" }\end{array}$ & $\begin{array}{l}\text { Journey of Electrical and } \\
\text { Electronics Engineering }\end{array}$ & $206-210$ & $1 / 2009$ \\
\hline & $\begin{array}{l}\text { Nevzat Onat } \\
\text { and } \\
\text { Sedat Ersoz }\end{array}$ & $\begin{array}{l}\text { "Analysis of wind climate and wind } \\
\text { energy potential of regions in Turkey" }\end{array}$ & Energy, vol. 36 & $148-156$ & 2011 \\
\hline & M. Mirhosseini, et al. & $\begin{array}{l}\text { "Assessing the wind energy potential } \\
\text { locations in province of Semnan in } \\
\text { Iran" }\end{array}$ & $\begin{array}{l}\text { Renewable and } \\
\text { Sustainable Energy } \\
\text { Reviews, vol. } 15\end{array}$ & $449-459$ & 2011 \\
\hline & M.R. Islam, et al. & $\begin{array}{l}\text { "Assessment of wind energy } \\
\text { potentiality at Kudat and Labuan, } \\
\text { Malaysia using } \\
\text { Weibull distribution function" }\end{array}$ & Energy, vol. 36 & $985-992$ & 2011 \\
\hline & H.W. Teetz, et al. & $\begin{array}{l}\text { "Assessment of the wind power } \\
\text { potential at SANAE IV base, } \\
\text { Antarctica: a technical and economic } \\
\text { feasibility study" }\end{array}$ & $\begin{array}{l}\text { Renewable Energy, } \\
\text { vol. } 28\end{array}$ & $\begin{array}{l}2037- \\
2061\end{array}$ & 2003 \\
\hline & $\begin{array}{l}\text { Khaled M. Bataineh and } \\
\text { Doraid Dalalah }\end{array}$ & $\begin{array}{l}\text { "Assessment of wind energy potential } \\
\text { for selected areas in Jordan" }\end{array}$ & $\begin{array}{l}\text { Renewable Energy, } \\
\text { vol. } 59\end{array}$ & $75-81$ & 2013 \\
\hline & $\begin{array}{l}\text { Michael J. Dvorak, } \\
\text { et al. }\end{array}$ & $\begin{array}{l}\text { "California offshore wind energy } \\
\text { potential" }\end{array}$ & $\begin{array}{l}\text { Renewable Energy, } \\
\text { vol. } 35\end{array}$ & $\begin{array}{l}1244- \\
1254 \\
\end{array}$ & 2010 \\
\hline & Jie Zhang, et al. & $\begin{array}{l}\text { "A comprehensive measure of the } \\
\text { energy resource: Wind power potential } \\
\text { (WPP)" }\end{array}$ & $\begin{array}{l}\text { Energy Conversion and } \\
\text { Management, vol. } 86\end{array}$ & $388-398$ & 2014 \\
\hline & $\begin{array}{l}\text { Yiannis A. Katsigiannis } \\
\text { and George S. Stavrakakis }\end{array}$ & $\begin{array}{l}\text { "Estimation of wind energy production } \\
\text { in various sites in Australia for } \\
\text { different wind turbine classes: A } \\
\text { comparative technical and economic } \\
\text { assessment" }\end{array}$ & $\begin{array}{l}\text { Renewable Energy, } \\
\text { vol. } 67\end{array}$ & $230-236$ & 2014 \\
\hline & $\begin{array}{l}\text { I. G. Damousis } \\
\text { and P. Dokopoulos }\end{array}$ & $\begin{array}{l}\text { "A Fuzzy Expert System for The } \\
\text { Forecasting of Wind Speed and Power } \\
\text { Generation in Wind Farms" }\end{array}$ & $\begin{array}{l}\text { Power Industry and } \\
\text { Computer Applications }\end{array}$ & $63-69$ & 2001 \\
\hline & Yi Gao, et al. & $\begin{array}{l}\text { "Composite Generation and } \\
\text { Transmission System } \\
\text { Reliability Evaluation Incorporating } \\
\text { Two Wind } \\
\text { Energy Facilities Considering Wind } \\
\text { Speed Correlation" } \\
\end{array}$ & $\begin{array}{l}\text { Conference Paper } \\
\text { Calgary, AB } \\
\text { North American Power } \\
\text { Symposium }\end{array}$ & $1-7$ & $\begin{array}{l}\text { Sept. 28- } \\
30,2008\end{array}$ \\
\hline & Geoffrey McD. Lewis & $\begin{array}{l}\text { "High value wind: A method to explore } \\
\text { the relationship between wind speed } \\
\text { and electricity locational marginal } \\
\text { price" }\end{array}$ & $\begin{array}{l}\text { Renewable Energy, } \\
\text { vol. } 33\end{array}$ & $\begin{array}{l}1843- \\
1853\end{array}$ & 2008 \\
\hline & P. Yeter, et al. & $\begin{array}{l}\text { "The Impact of Wind Speed Variability } \\
\text { on Wind Power Potential and } \\
\text { Estimated Generation Cost" }\end{array}$ & $\begin{array}{l}\text { Energy Sources, Part B: } \\
\text { Economics, } \\
\text { Planning, and Policy, vol. } \\
7\end{array}$ & $339-347$ & 2012 \\
\hline & Lin Lu, et al. & $\begin{array}{l}\text { "Investigation on wind power potential } \\
\text { on Hong Kong islands - an analysis of } \\
\text { wind power and wind turbine } \\
\text { characteristics" }\end{array}$ & $\begin{array}{l}\text { Renewable Energy, } \\
\text { vol. } 27\end{array}$ & $1-12$ & 2000 \\
\hline & Ahmed Shata Ahmed & $\begin{array}{l}\text { "Investigation of wind characteristics } \\
\text { and wind energy potential at Ras } \\
\text { Ghareb, Egypt" }\end{array}$ & $\begin{array}{l}\text { Renewable and } \\
\text { Sustainable Energy } \\
\text { Reviews, vol. } 15\end{array}$ & $\begin{array}{l}2050- \\
2055\end{array}$ & 2011 \\
\hline & $\begin{array}{l}\text { Corinne Wichser } \\
\text { and } \\
\text { Katherine Klink }\end{array}$ & $\begin{array}{l}\text { "Low wind speed turbines and wind } \\
\text { power potential in Minnesota, USA" }\end{array}$ & $\begin{array}{l}\text { Renewable Energy, } \\
\text { vol. } 33\end{array}$ & $\begin{array}{l}1749- \\
1758\end{array}$ & 2008 \\
\hline & & "Potential wind power generation in & Renewable and & $1528-$ & \\
\hline
\end{tabular}


2015 Proceedings of PICMET '15: Management of the Technology Age

\begin{tabular}{|c|c|c|c|c|c|}
\hline & Ahmed Shata Ahmed & South Egypt" & $\begin{array}{l}\text { Sustainable Energy } \\
\text { Reviews, vol. } 16\end{array}$ & 1536 & 2012 \\
\hline & G. Suchitra, et al. & $\begin{array}{l}\text { "Reliability Evaluation of Wind Power } \\
\text { in North Karnataka, India - A Case } \\
\text { Study" }\end{array}$ & $\begin{array}{l}\text { IEEE Conference on } \\
\text { Sustainable Energy } \\
\text { Technologies }\end{array}$ & $478-482$ & $\begin{array}{l}\text { Nov. 24- } \\
27,2008\end{array}$ \\
\hline & $\begin{array}{l}\text { Mark Z. Jacobson } \\
\text { and Cristina L. Archer }\end{array}$ & $\begin{array}{l}\text { "Saturation wind power potential and } \\
\text { its implications for wind energy" }\end{array}$ & $\begin{array}{l}\text { Proceeding of the National } \\
\text { Academy of Sciences of the } \\
\text { United States of America, } \\
\text { vol. } 109, \text { no. } 39\end{array}$ & $\begin{array}{l}15679- \\
15684\end{array}$ & $\begin{array}{l}\text { Set. 25, } \\
2012\end{array}$ \\
\hline & J.N. Kamau, et al. & $\begin{array}{l}\text { "6 years of wind data for Marsabit, } \\
\text { Kenya average over } 14 \mathrm{~m} / \mathrm{s} \text { at } 100 \mathrm{~m} \\
\text { hub height; An analysis of the wind } \\
\text { energy potential" }\end{array}$ & $\begin{array}{l}\text { Renewable Energy, } \\
\text { vol. } 35\end{array}$ & $\begin{array}{l}1298- \\
1302\end{array}$ & 2010 \\
\hline & $\begin{array}{l}\text { Bonfils Safari } \\
\text { and } \\
\text { Jimmy Gasore }\end{array}$ & $\begin{array}{l}\text { "A statistical investigation of wind } \\
\text { characteristics and wind energy } \\
\text { potential based on the Weibull and } \\
\text { Rayleigh models in Rwanda" }\end{array}$ & $\begin{array}{l}\text { Renewable Energy, } \\
\text { vol. } 35\end{array}$ & $\begin{array}{l}2874- \\
2880\end{array}$ & 2010 \\
\hline & Xiaoxia Gao, et al. & $\begin{array}{l}\text { "Study on offshore wind power } \\
\text { potential and wind farm optimization in } \\
\text { Hong Kong" }\end{array}$ & $\begin{array}{l}\text { Applied Energy, } \\
\text { vol. } 130\end{array}$ & $519-530$ & 2014 \\
\hline & $\begin{array}{l}\text { Shahnawaz Farhan Khahro, } \\
\text { et al. }\end{array}$ & $\begin{array}{l}\text { "Techno-economical evaluation of } \\
\text { wind energy potential and analysis of } \\
\text { power generation from wind at Gharo, } \\
\text { Sindh Pakistan" }\end{array}$ & $\begin{array}{l}\text { Renewable and } \\
\text { Sustainable Energy } \\
\text { Reviews, vol. } 35\end{array}$ & $460-474$ & 2014 \\
\hline & Hsin-Fa Fang & $\begin{array}{l}\text { "Wind energy potential assessment for } \\
\text { the offshore areas of Taiwan west coast } \\
\text { and Penghu Archipelago" }\end{array}$ & $\begin{array}{l}\text { Renewable Energy, } \\
\text { vol. } 67\end{array}$ & $237-241$ & 2014 \\
\hline & M.A. Alsaad & $\begin{array}{l}\text { "Wind energy potential in selected } \\
\text { areas in Jordan" }\end{array}$ & $\begin{array}{l}\text { Energy Conversion and } \\
\text { Management, vol. } 65\end{array}$ & $704-708$ & 2013 \\
\hline & $\begin{array}{l}\text { Cumali I' lkilic } \\
\text { and Ismail Turkbay }\end{array}$ & $\begin{array}{l}\text { "Determination and utilization of wind } \\
\text { energy potential for Turkey" }\end{array}$ & $\begin{array}{l}\text { Renewable and } \\
\text { Sustainable Energy } \\
\text { Reviews, vol. } 14\end{array}$ & $\begin{array}{l}2202- \\
2207\end{array}$ & 2010 \\
\hline & Jie Zhang, et al. & $\begin{array}{l}\text { "A comprehensive measure of the } \\
\text { energy resource: Wind power potential } \\
\text { (WPP)" }\end{array}$ & $\begin{array}{l}\text { Energy Conversion and } \\
\text { Management, vol. } 86\end{array}$ & $388-398$ & 2014 \\
\hline & Kaigui Xie, et al. & $\begin{array}{l}\text { "Effect of Wind Speed on Wind } \\
\text { Turbine Power Converter Reliability" }\end{array}$ & $\begin{array}{l}\text { IEEE Transactions on } \\
\text { Energy Conversion, vol. } \\
27, \text { no. } 1\end{array}$ & $96-104$ & $\begin{array}{l}\text { March } \\
2012\end{array}$ \\
\hline & Y. Himri, et al. & $\begin{array}{l}\text { "Wind power potential assessment for } \\
\text { three locations } \\
\text { in Algeria" }\end{array}$ & $\begin{array}{l}\text { Renewable and } \\
\text { Sustainable Energy } \\
\text { Reviews, vol. } 12\end{array}$ & $\begin{array}{l}2495- \\
2504\end{array}$ & 2008 \\
\hline & S.S. Chandel, et al. & $\begin{array}{l}\text { "Wind power potential assessment of } \\
12 \text { locations in western Himalayan } \\
\text { region of India" }\end{array}$ & $\begin{array}{l}\text { Renewable and } \\
\text { Sustainable Energy } \\
\text { Reviews, vol. } 39\end{array}$ & $530-545$ & 2014 \\
\hline & A.H. Al-Badi & "Wind power potential in Oman" & $\begin{array}{l}\text { International Journal of } \\
\text { Sustainable Energy, vol. } \\
30, \text { no. } 2\end{array}$ & $110-118$ & $\begin{array}{l}\text { Apr. } \\
2011\end{array}$ \\
\hline & Wei Zhou, et al. & $\begin{array}{l}\text { "Wind power potential and } \\
\text { characteristic analysis of the Pearl } \\
\text { River Delta region, China" }\end{array}$ & $\begin{array}{l}\text { Renewable Energy, } \\
\text { vol. } 31\end{array}$ & $739-753$ & 2006 \\
\hline & Bonfils Safari, et al. & $\begin{array}{l}\text { "A statistical investigation of wind } \\
\text { characteristics and wind energy } \\
\text { potential based on the Weibull and } \\
\text { Rayleigh models in Rwanda" }\end{array}$ & $\begin{array}{l}\text { Renewable Energy, } \\
\text { vol. } 35\end{array}$ & $\begin{array}{l}2874- \\
2880\end{array}$ & 2010 \\
\hline & Grigorios Marmidis, et al. & $\begin{array}{l}\text { "Optimal placement of wind turbines in } \\
\text { a wind park using Monte Carlo } \\
\text { simulation" }\end{array}$ & $\begin{array}{l}\text { Renewable Energy, } \\
\text { vol. } 33\end{array}$ & $\begin{array}{l}1455- \\
1460\end{array}$ & 2008 \\
\hline : & S.A. Grady, et al. & $\begin{array}{l}\text { "Placement of wind turbines using } \\
\text { genetic algorithms" }\end{array}$ & $\begin{array}{l}\text { Renewable Energy, } \\
\text { vol. } 30\end{array}$ & $259-270$ & 2005 \\
\hline 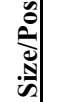 & $\begin{array}{l}\text { Bogdan S. Borowy } \\
\text { and Ziyad M. Salameh }\end{array}$ & $\begin{array}{l}\text { "Optimum Photovoltaic Array Size for } \\
\text { a Hybrid Wind/PV System" }\end{array}$ & $\begin{array}{l}\text { IEEE Transactions on } \\
\text { Energy Conversion, vol.9, } \\
\text { no. } 3\end{array}$ & $482-488$ & $\begin{array}{l}\text { Sept. } \\
1994\end{array}$ \\
\hline$\underset{:}{\stackrel{:}{: \mid}}$ & G. Mosetti, et al. & $\begin{array}{l}\text { "Optimization in wind turbine } \\
\text { positioning in large windfarms by } \\
\text { means of a genetic algorithm" }\end{array}$ & $\begin{array}{l}\text { Journal of Wind } \\
\text { Engineering and } \\
\text { Aerodynamics, } \\
\text { vol. } 51\end{array}$ & $105-116$ & 1994 \\
\hline & $\begin{array}{l}\text { Leonardo P. Chamorro, et } \\
\text { al. }\end{array}$ & $\begin{array}{l}\text { "Variable-sized wind turbines are a } \\
\text { possibility for wind } \\
\text { farm optimization" }\end{array}$ & Wind energy, vol. 17 & $\begin{array}{l}1483- \\
1494\end{array}$ & 2014 \\
\hline
\end{tabular}


2015 Proceedings of PICMET '15: Management of the Technology Age

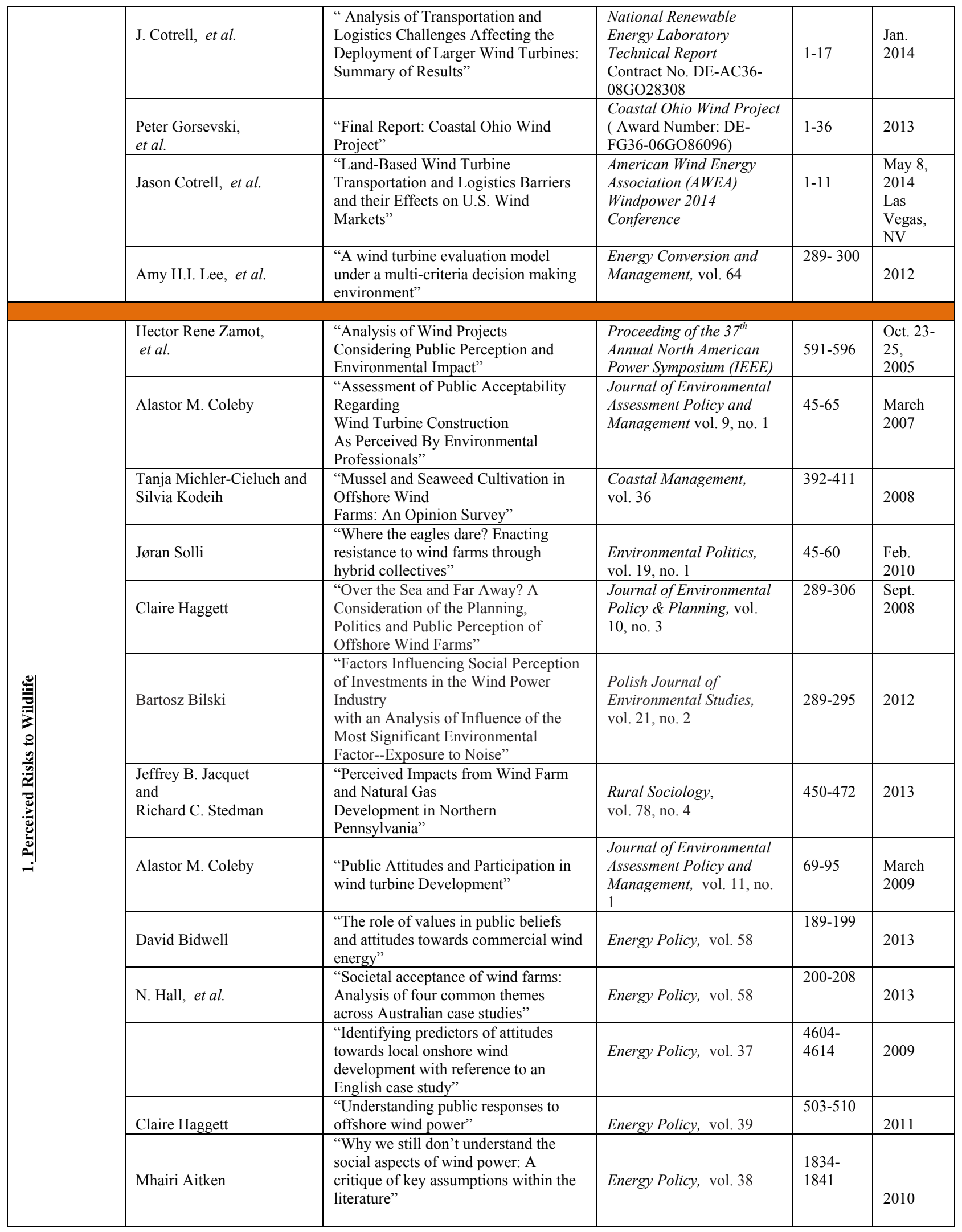


2015 Proceedings of PICMET '15: Management of the Technology Age

\begin{tabular}{|c|c|c|c|c|c|}
\hline \multirow{5}{*}{ 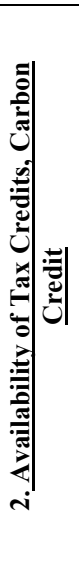 } & Yao Yin & $\begin{array}{l}\text { "An analysis of empirical cases of } \\
\text { community wind in Oregon" }\end{array}$ & $\begin{array}{l}\text { Renewable and } \\
\text { Sustainable Energy } \\
\text { Reviews, vol. } 17\end{array}$ & $54-73$ & 2013 \\
\hline & C.G. Dong & $\begin{array}{l}\text { "Feed-in tariff vs. renewable portfolio } \\
\text { standard: An empirical test of their } \\
\text { relative effectiveness in promoting } \\
\text { wind capacity development" }\end{array}$ & Energy Policy, vol. 42 & $476-485$ & 2012 \\
\hline & $\begin{array}{l}\text { Gabriella Stockmayer, } \\
\text { et al. }\end{array}$ & $\begin{array}{l}\text { "Limiting the costs of renewable } \\
\text { portfolio standards: A review and } \\
\text { critique of current methods" }\end{array}$ & Energy Policy, vol. 42 & $155-163$ & 2012 \\
\hline & $\begin{array}{l}\text { Fredric C. Menz } \\
\text { and } \\
\text { Stephan Vachon }\end{array}$ & $\begin{array}{l}\text { "The effectiveness of different policy } \\
\text { regimes for promoting wind power: } \\
\text { Experiences from the states" }\end{array}$ & Energy Policy, vol. 34 & $\begin{array}{l}1786- \\
1796\end{array}$ & 2006 \\
\hline & Yao Yin & $\begin{array}{l}\text { "A socio-political analysis of policies } \\
\text { and incentives applicable to } \\
\text { community wind in Oregon" }\end{array}$ & Energy Policy, vol. 42 & $442-449$ & 2012 \\
\hline \multirow{9}{*}{ 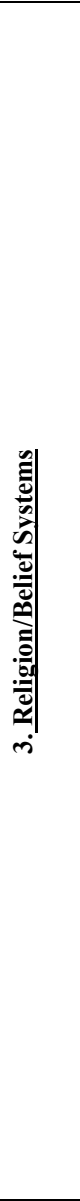 } & M.W. Marinakos & $\begin{array}{l}\text { "A Mighty Wind: } \\
\text { The Turbulent Times of America's } \\
\text { First Offshore Wind Farm and The } \\
\text { Inverse of Environmental Justice" }\end{array}$ & $\begin{array}{l}\text { Journal Earth } \\
\text { Jurisprudence \& } \\
\text { Environmental Justice, } \\
\text { vol. } 82\end{array}$ & $82-117$ & 2012 \\
\hline & Kathleen M. Saul & $\begin{array}{l}\text { "Cape Wind and the Sacred Sunrise of } \\
\text { the Wampanoag: } \\
\text { A Victory for Whom?" }\end{array}$ & $\begin{array}{l}\text { Evergreen State College } \\
\text { Native Case Study } \\
\text { NSF Grant no. } 0817624 \\
\text { Available: } \\
\text { http://nativecases.evergree } \\
\text { n.edu/ } \\
\end{array}$ & $1-23$ & 2010 \\
\hline & $\begin{array}{l}\text { Kathleen Pickering and } \\
\text { Benjamin Jewell }\end{array}$ & $\begin{array}{l}\text { "Nature is Relative: Religious } \\
\text { Affiliation, Environmental Attitudes, } \\
\text { and Political Constraints on the Pine } \\
\text { Ridge Indian Reservation" }\end{array}$ & $\begin{array}{l}\text { Journal for the Study of } \\
\text { Religion, Nature and } \\
\text { Culture }\end{array}$ & $135-158$ & 2008 \\
\hline & Dominic Spinelli & $\begin{array}{l}\text { "Historic Preservation \& Offshore } \\
\text { Wind Energy: Lessons } \\
\text { Learned from the Cape Wind Saga" }\end{array}$ & $\begin{array}{l}\text { Gonzaga Law Review, vol. } \\
46, \text { no. } 3\end{array}$ & $741-770$ & $\begin{array}{l}2010 / \\
2011\end{array}$ \\
\hline & D.J. Hurlbut, et al. & $\begin{array}{l}\text { "Navajo Generating Station and Clean- } \\
\text { Energy Alternatives: Options for } \\
\text { Renewables" }\end{array}$ & $\begin{array}{l}\text { U.S. DOE/NREL Technical } \\
\text { Report } \\
\text { Contract No. DE-AC36- } \\
\text { 08GO28308 }\end{array}$ & $1-35$ & $\begin{array}{l}\text { June } \\
2012\end{array}$ \\
\hline & Euel Elliott, et al. & $\begin{array}{l}\text { "Political and Economic Determinants } \\
\text { of Individuals' Support for } \\
\text { Environmental Spending" }\end{array}$ & $\begin{array}{l}\text { Journal of Environmental } \\
\text { Management, vol. } 51\end{array}$ & $15-27$ & 1997 \\
\hline & Bob Congleton & $\begin{array}{l}\text { "The Tribal Energy Program: Wind } \\
\text { Power and Human Development within } \\
\text { Native American Communities" }\end{array}$ & $\begin{array}{l}\text { Capstone Project; } M A \\
\text { Political Studies } \\
\text { Interdisciplinary Arts and } \\
\text { Sciences, University of } \\
\text { Washington Bothell } \\
\end{array}$ & $1-43$ & 2013 \\
\hline & $\begin{array}{l}\text { M. Niels Peterson and } \\
\text { Jianguo Liu }\end{array}$ & $\begin{array}{l}\text { "Impacts of Religion on Environmental } \\
\text { Worldviews: } \\
\text { The Teton Valley Case" }\end{array}$ & $\begin{array}{l}\text { Society \& Natural } \\
\text { Resources: An } \\
\text { International Journal }\end{array}$ & $704-718$ & 2008 \\
\hline & $\begin{array}{l}\text { Richard Hindmarsh } \\
\text { and } \\
\text { Catherine Matthews }\end{array}$ & $\begin{array}{l}\text { "Deliberative Speak at the Turbine } \\
\text { Face: Community } \\
\text { Engagement, Wind Farms, and } \\
\text { Renewable Energy Transitions, in } \\
\text { Australia" }\end{array}$ & $\begin{array}{l}\text { Journal of Environmental } \\
\text { Management \& Planning, } \\
\text { vol. } 10, \text { no. } 3\end{array}$ & $217-232$ & $\begin{array}{l}\text { Sept. } \\
2008\end{array}$ \\
\hline \multirow{4}{*}{ 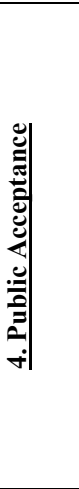 } & $\begin{array}{l}\text { Alexandros Dimitropoulos } \\
\text { and } \\
\text { Andreas Kontoleon }\end{array}$ & $\begin{array}{l}\text { "Deliberative Speak at the Turbine } \\
\text { Face: Community } \\
\text { Engagement, Wind Farms, and } \\
\text { Renewable Energy Transitions, in } \\
\text { Australia" }\end{array}$ & $\begin{array}{l}\text { Energy Policy } \\
\text { vol. } 37\end{array}$ & $\begin{array}{l}1842- \\
1854\end{array}$ & 2009 \\
\hline & Geoff Riddington, et al. & $\begin{array}{l}\text { "Assessing the Economic Impact of } \\
\text { Wind Farms on Tourism in Scotland: } \\
\text { GIS, Surveys and Policy Outcomes" }\end{array}$ & $\begin{array}{l}\text { International Journal of } \\
\text { Tourism Research, } \\
\text { vol. } 12\end{array}$ & $237-252$ & 2010 \\
\hline & $\begin{array}{l}\text { Jacob Ladenburg } \\
\text { and } \\
\text { Bernd Möller }\end{array}$ & $\begin{array}{l}\text { "Attitude and acceptance of offshore } \\
\text { wind farms-The influence of travel } \\
\text { time and } \\
\text { wind farm attributes }\end{array}$ & $\begin{array}{l}\text { Renewable and } \\
\text { Sustainable Energy } \\
\text { Reviews, vol. } 15\end{array}$ & $\begin{array}{l}4223- \\
4235\end{array}$ & 2011 \\
\hline & Jacob Ladenburg & $\begin{array}{l}\text { "Attitudes towards on-land and } \\
\text { offshore wind power development in } \\
\text { Denmark; choice of development }\end{array}$ & $\begin{array}{l}\text { Renewable Energy, vol. } \\
33\end{array}$ & $111-118$ & 2008 \\
\hline
\end{tabular}


2015 Proceedings of PICMET '15: Management of the Technology Age

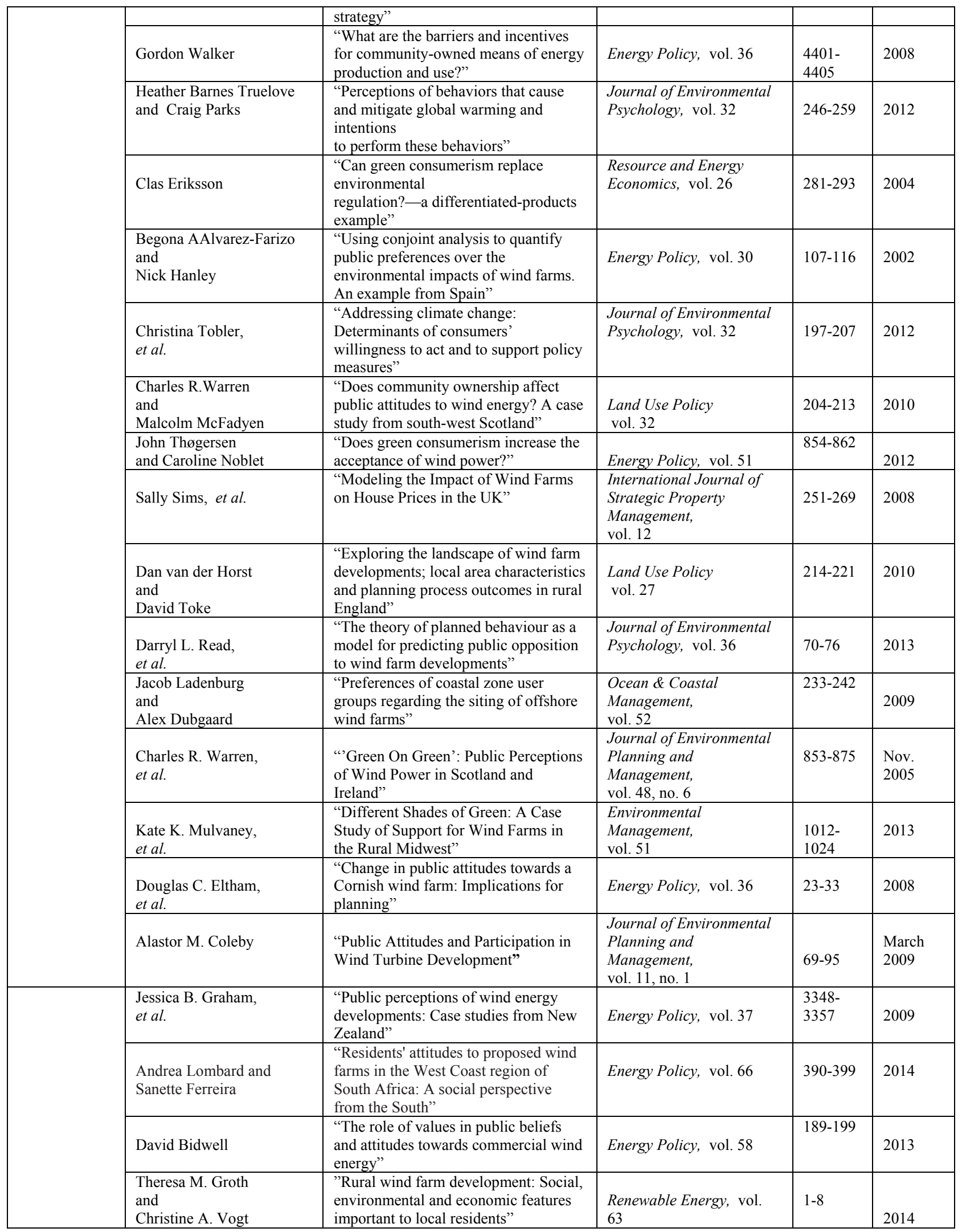

